Zavoda za znanstveni rad

\title{
GIMNAZIJSKI OMLADINSKI KLUB V3
}

Omladinski klub V3 varaždinske Gimnazije utemeljen je 21. rujna 1965. godine na obljetnicu stradanja V3 (petog tri) razreda kragujevačkih učenika prema kojem je dobio ime. U početku je djelovao u bivšoj crtaoni, najvećoj prostoriji u varaždinskoj Gimnaziji. Nakon rekonstrukcije gimnazijske zgrade u periodu 1971.-1973. godine, za njegove je potrebe, uz dobrovoljni rad učenika, bio uređen podrumski prostor južnog krila Gimnazije u kojem je nastavio uspješno djelovati do izbijanja ratnih sukoba koji su početkom 90-ih godina XX. stoljeća prouzročili raspad Jugoslavije i osnutak neovisne Republike Hrvatske.

Djelujući kao učenički klub koji je imao ograničenu autonomiju unutar škole, razvijao je bogatu i razgrananu aktivnost, priređujući javna događanja, kulturne i zabavne priredbe namijenjene gimnazijalcima, a često i široj publici. Zahvaljujući vlastitim prihodima, Klub je dijelom bio financijski neovisan, a njegovim su radom, uz indirektan nadzor škole, uglavnom samostalno upravljali učenici. U njegovoj su organizaciji pred gimnazijskim učenicima nastupali i izvodili svoje programe istaknuti umjetnici, književnici, glazbenici i glazbeni sastavi, znanstvenici, sportaši i društveno-politički aktivisti i djelatnici s područja čitave Jugoslavije. Polaznicima Gimnazije je tako bilo omogućeno, ne samo korisno provođenje slobodnog vremena, već i mladima svojstvena zabava jer je Klub redovito, jednom tjedno priređivao disco-večeri i godinama bio jedini disco-klub u Varaždinu.

Izbijanjem Domovinskog rata i izmjenom društveno-političkog i gospodarskog sustava početkom 90-ih godina XX. stoljeća, djelovanje Omladinskog kluba V3 je spontano prekinuto. Njegov neiskorišteni prostor uprava varaždinske Gimnazije odlučila je iskoristiti kako bi osigurala brzu prehranu za potrebe svojih učenika.

Ključne riječi: Prva gimnazija Varaždin; učenički klub; kulturni i zabavni život mladih; Varaždin. 


\section{UVOD}

Tijekom gotovo četiri stoljeća povijesti varaždinske Gimnazije pod njenim su okriljem djelovale brojne udruge, okupljajući njene polaznike oko ideja kojima je obogaćivan odgojno-obrazovni proces. Kako su u početku školom upravljali crkveni redovi, one su prvo bile vjerskog karaktera. No s laicizacijom školskog sustava, ubrzo su se počele osnivati udruge kulturno-umjetničkog, znanstvenog, sportskog, humanitarnog, a ovisno o prirodi trenutno vladajućeg političkog sustava, i udruge političkog karaktera. Uglavnom su djelovale kao podmladak udruga koje su od vladajućeg sustava dobivale odobrenje za svoj rad u školi, a obično su ih vodili pojedini profesori, okupljajući učenike sklone prihvaćanju ideja i ciljeva koje su zastupale. Manji broj takvih učeničkih udruga, poput literarnog društva Neven ili Varaždinskog gimnazijskog športskog kluba, nastajao je kao posebne, samostalne udruge, inspirirane specifičnim potrebama i sklonostima samih učenika.

Osnutak učeničkog kluba koji bi okupljao učenike na temeljima samoinicijative i samouprave, s ciljem da kreira raznovrsne aktivnosti i programe na principima vršnjačke suradnje i samoorganiziranja, pojavio se tek u prvoj polovini XX. stoljeća. Donekle se tome približilo Učeničko društvo "Svačić" koje je početkom stoljeća nastalo kao udruga glazbenog karaktera, ali se kasnije razvilo kao udruga s razgranatom djelatnošću čije su aktivnosti često samostalno provodili sami učenici. Kako se njegovo djelovanje poklapalo s periodom jugoslavenske monarhističke diktature, njegov je rad unaprijed bio strogo propisan krutim pravilima te je sustavno nadziran od školskih vlasti. Omladinski klub V3 znatno se više približio ostvarivanju ovih principa, iako je bio osnovan na poticaj organizacije Socijalističke Omladine i pod nadzorom socijalističkog sustava. Okupljajući polaznike varaždinske Gimnazije, on je kvalitetom svojih programa obrazovnog, kulturnog i zabavnog karaktera, tijekom više od četvrt stoljeća, osim gimnazijalaca privlačio mladež čitavog Varaždina, nadoknađujući i zamjenjujući nepostojeći omladinski dom. 


\section{OSNUTAK OMLADINSKOG KLUBA V3}

Nastanak novog učeničkog kluba varaždinskih gimnazijalaca u razdoblju socijalističke Jugoslavije seže u 60-te godine XX. stoljeća. Povezan je s pokušajima da se u periodu stalnog rasta broja gimnazijskih učenika, osigura odgovarajući prostor namijenjen boravku učenika putnika. Kako je 1950. godine u jugoslavenskom školskom sustavu uslijedila radikalna promjena koja se očitovala u prijelazu na osmogodišnje osnovno obrazovanje, to je podrazumijevalo i preobrazbu Gimnazije u četverogodišnju srednju školu. Od 1955./56. godine, njeni niži razredi postupno su uklapani u osmogodišnje osnovne škole. ${ }^{1}$ Od šk. g. 1956./57., objedinjavanjem dotad razdvojenih uprava Muške i Ženske gimnazije, ponovno je oblikovana jedinstvena varaždinska Gimnazija. ${ }^{2}$ Tijekom ovih promjena naglo je porastao i broj paralelnih razreda. Početkom 50 -ih godina u završnom razredu obiju varaždinskih gimnazija bile su 2 do 3 , a nakon spomenute fuzije u završni razred upisano je 6 paralelki. Godine 1960./61. uslijedila je izmjena nastavnih planova i programa prema kojoj su se polaznici 2. razreda, ovisno o sklonostima, mogli opredijeliti za prirodoslovno-matematički ili društveno-jezični smjer. Zamijećen je daljnji porast zanimanja za školovanje u Gimnaziji, pa je rastao ukupan broj učenika, dok je broj razreda dosegao 30, čime je ova škola postala jedna od najvećih u državi. ${ }^{3} \mathrm{U}$ varaždinsku Gimnaziju je upisivan sve veći broj polaznika koji su u školu morali putovati, prilagođavajući se postojećim prometnim mogućnostima.

Tipičnu sliku učenika putnika varaždinske okolice sredine 60 -ih godina predstavljali su učenici koji su se svakodnevno budili u ranim jutarnjim satima kako bi nakon napornog pješačenja, stizali na radničke vlakove. Kako im je nastava ujutro počinjala tek $\mathrm{u} 8 \mathrm{~h}$, putnici su vrijeme do početka nastave najčešće provodili na kolodvoru ili lutajući gradom. Po završetku nastave oni bi morali čekati do polaska povratnih vlakova pa su se neki od njih, nakon vožnje i pješačenja, vraćali kući kasno popodne. Ideja o osnutku novog učeničkog kluba bila je inspirirana jednom takvom pričom s kojom se imao prilike upoznati Dimitrije Savić, tada istaknuti aktivist gimnazijske Omladinske organizacije, razgovarajući sa starijim kolegom Zlatkom Banićem. ${ }^{4}$ Zahvaljujući tome se u gimnazijskoj Omladinskoj or-

\footnotetext{
"Velik priliv učenika u gimnazije", Varaždinske vijesti, 8. IX. 1955., br. 497., str. 3.

"Jedinstvena gimnazija u Varaždinu", Varaždinske vijesti, 14. VI. 1956., br. 537., str. 6.

“Još nisu svi upisani", Varaždinske vijesti, 7. IX. 1967., br. 1189., str. 6.

Iz pisma g. Andreja Dermola, jednog od sudionika u osnivanju Kluba autoru saznajemo da je Zlatko Banić živio u okolini Bednje i ustajao oko 4h ujutro kako bi nakon jednosatnog pješačenja stigao na radnički vlak koji je u Varaždin dolazio nešto prije 6 . Vrijeme do početka nastave, posebno zimi,
} 
ganizaciji oblikovala ideja o nalaženju i opremanju prostora u kojem bi svi oni koji su bili u sličnoj situaciji, mogli boraviti do početka i nakon završetka nastave do polaska povratnih vlakova. Tu bi učenici mogli rješavati zadaće, učiti za sljedeći dan ili bi provodili vrijeme u razgovoru i druženju. Spomenuti Dimitrije Savić je s tom namjerom predložio osnivanje učeničkog kluba, a prijedlog je naišao na podršku ravnatelja, prof. Josipa Runjaka i proslijeđen na razmatranje u Općinski komitet Saveza komunista. Po dobivanju odobrenja uslijedila je realizacija ideje, čemu je, prema riječima samih inicijatora, veliku podršku pružila prof. Emina Gomaz. $^{5}$

Pri odabiru naziva novog učeničkog kluba ključnu je ulogu odigrala tada vladajuća ideja bratstva i jedinstva i praksa bratimljenja s gradovima iz ostalih republika. Varaždin je u tom periodu uspostavljao prisne veze $s$ gradom Kragujevcom iz SR Srbije. Premda je među profesorima bilo i drugih mišljenja, Klub je nazvan Omladinski klub V3. Iako to ime nije imalo uporišta ni u tradiciji ni u revolucionarnoj praksi ovog kraja, zahvaljujući aktualnom ozračju, bilo je prihvaćeno. Prema riječima samih osnivača, pri njegovom odabiru velik su utjecaj imali Krvava bajka, tragična ratna poema pjesnikinje Desanke Maksimović i film s aktualnom tematikom. U njima su na potresan način oslikana stradanja čitavog razreda kragujevačkih učenika, koje je u odmazdi za partizanske akcije, strijeljala njemačka vojska. ${ }^{6}$

Omladinski klub V3 službeno je počeo djelovati 21. listopada 1965. godine, na obljetnicu spomenute tragedije. Tom prilikom je mladež u prostorima bivše gimnazijske crtaone, tada najveće prostorije u školi, priredila prigodnu svečanost. Osim učenika, članova Kluba koji su ispunili prostranu dvoranu, svečanosti su, uz ostale uzvanike prisustvovale i ključne osobe iz varaždinskog društvenopolitičkog života. ${ }^{7}$ Prema novinskim izvještajima: "Svečanost je počela izvrsno zamišljenim i decentno izvedenim recitalom posvećenim dramatičnoj pogibiji kragujevačkih đaka u izvedbi grupe recitatora - učenika Gimnazije i njihovih gostiju

obično bi proboravio u zagrijanim prostorima varaždinskog kolodvora, gubeći puna dva sata. Po završetku šestosatne nastave, morao bi besposlen čekati do polaska povratnog vlaka iza $15 \mathrm{~h}$ te bi se, nakon putovanja i pješačenja, obično vratio kući tek iza $17 \mathrm{~h}$.

5 Isto.

6 Pismo g. Dermola, jednog od sudionika u osnivanju Kluba autoru.

7 Priredbu su svojom prisutnošću uveličali Valent Huzjak, politički sekretar varaždinskog Kotarskog komiteta SK, Vjekoslav Lujo Keretić, predsjednik Skupštine općine Varaždin i Pavao Lepen, tajnik varaždinskog Kotarskog odbora Saveza Socijalističkog Radnog Naroda Hrvatske. U realizaciji programa posebno se kao recitator istaknuo Zlatko Svalina, dok su u nastavku programa vlastite radove čitale članice literarne grupe: Ksenija Jović, Marinka Piskač, Biserka Kukec, Gordana Ozimec i Mira Posavec. 
- omladinaca, pripadnika JNA". ${ }^{8} \mathrm{U}$ prigodnim izlaganjima bilo je najavljeno kako će netom osnovani učenički klub kroz svoje djelovanje nastojati objedinjavati korisno i zabavno pa su mu namijenjeni zadatci bili višestruki. Vodstvo Kluba u početku se sastojalo od predsjednika, tajnika, blagajnika i tročlanog odbora. Ono je izradilo pravilnik Kluba i organiziralo dežurstva potrebna prilikom odvijanja pojedinih aktivnosti. Odluke su donošene na redovitim sastancima rukovodstva na kojima su rješavana goruća pitanja. ${ }^{9}$ Nastavničko vijeće je iz svojih redova zadužilo voditelja Kluba sa zadaćom da pomogne mladeži. Tu je ulogu godinama izuzetno uspješno obnašao prof. Franjo Bračko. ${ }^{10}$

Za potrebe djelovanja Kluba bila je namijenjena već spomenuta dvorana bivše crtaone na II. katu južnog krila školske zgrade koju su u tu svrhu uredili i opremili sami učenici. Ona je ujedno trebala služiti za boravak učenika-putnika između nastave i dolaska odnosno polaska vlakova. Njima, kao i ostalim članovima Kluba stavljene su na raspolaganje društvene igre i novine pa su se tijekom odmora ili slobodnog vremena, okupljali učenici zainteresirani za nadmetanja u šahu. Već u prvim mjesecima u Klub se učlanilo 500-tinjak učenika. Kako su organizatori poslovanje Kluba namjeravali razvijati na ekonomskim principima, dio prihoda trebala je predstavljati članarina, ${ }^{11}$ no od njenog ubiranja se odustalo. ${ }^{12}$ Nastojeći samostalno financirati svoju djelatnost, Klub je želio bar djelom zadovoljiti raznovrsne interese gimnazijske mladeži. Kako je za njegove potrebe osiguran kino-projektor, bilo je planirano redovito priređivanje kino-predstava. Projekcije filmova u početku su se održavale dva puta tjedno te je već u prvim mjesecima prikazano 17 filmova, a u navedenom su razdoblju priređene ukupno 34 projekcije. ${ }^{13}$ Subotom su bile predviđene plesne večeri za što je prikupljena relativno bogata diskoteka. U klupskom prostoru planirani su raznovrsni prigodni programi te su povremeno priređivane uspješne literarne, dramske i debatne večeri. ${ }^{14}$ Potrebna sredstva pribavljana su i kroz donacije. Jedva dva mjeseca nakon njegovog osnivanja, sindikalna podružnica općinske uprave Skupštine općine

\footnotetext{
8 "U varaždinskoj Gimnaziji osnovan je Omladinski klub V/3", Varaždinske vijesti, br. 43 od 28. X. 1965., str. 2.

9 "Polugodišnji izvještaj rada OK V3 Gimnazije Varaždin", Gimnazijalac, list Saveza omladine Gimnazije Varaždin, br. 1 od 1. veljače 1966.

10 Profesor Bračko bio je predavač Predvojničke obuke, kasnije Općenarodne obrane i društvene samozaštite (op. a.).

11 "U varaždinskoj Gimnaziji osnovan je Omladinski klub V/3", Varaždinske vijesti, br. 43 od 28. X. 1965., str. 2.

12 Članarinu su u početku članovi Kluba trebali uplaćivati u iznosu od 100 din mjesečno (op. a.).

13 "Polugodišnji izvještaj rada OK V3 Gimnazije Varaždin", Gimnazijalac, br. 1 od 1. veljače 1966.

14 Isto, Varaždinske vijesti, br. 43 od 28. X. 1965., str. 2.
} 
Varaždin poklonila mu je svotu od 100.000 din. koja je, prema riječima predsjednice Kluba Dunje Sever, trebala poslužiti za nabavu TV-prijemnika, dok je poklonjeni radio upotpunio inventar Kluba. ${ }^{15}$ Nabavkom razglasnih uređaja ozvučene su učionice pa je, uz prenošenje vijesti, učenicima za vrijeme odmora omogućeno slušanje glazbe. Bitan zadatak Kluba bio je odgojno-obrazovne naravi. Već u prvim mjesecima njegovog djelovanja u organizaciji IV $\mathrm{f}$ i III a razreda, priređeno je 6 zanimljivih predavanja ilustriranih dia-filmovima. ${ }^{16}$

Na samu godišnjicu osnutka Kluba, 21. listopada 1966. u njegovoj dvorani održana je svečana priredba kojom su učenici i nastavni kadar Gimnazije obilježili 330-godišnjicu škole. Program je ujedno poslužio kao smotra rada slobodnih aktivnosti škole, a kao gosti su mu prisustvovali Lujo Keretić, predsjednik Skupštine općine i delegacija Gimnazije pobratimskog Kragujevca. ${ }^{17}$ Održavanje prisnih veza s Kragujevcom nastavilo se i na drugim područjima pa su u okviru svoje turneje dramski umjetnici iz Kragujevca ujesen 1967., posjetili i Varaždin. Tom prilikom priređen je njihov susret s članstvom Kluba i školskom mladeži. ${ }^{18}$

Godina 1966. za varaždinsku Gimnaziju se pokazala kao izuzetno uspješna jer je na natjecanju srednjih škola pod pokroviteljstvom lista Mladost bila proglašena najuspješnijom školom u SFRJ. Čak četiri njena razreda bila su ubrojena među deset najboljih u državi. ${ }^{19} \mathrm{Na}$ svečanosti održanoj 14. siječnja 1967., nagradu je predstavnicima gimnazije uručio Marko Lolić, direktor lista Mladost. ${ }^{20} \mathrm{U}$ ime gimnazijske mladeži nagradu je primila Jagoda Vadla, predsjednica omladinskog aktiva Gimnazije. U okviru prigodnog programa priređenog u tu svrhu, uz iznimno kvalitetne recitatore, po prvi puta je nastupila Humorističko dramskodekintirana nakupina Potepuhi koji su kasnije sa svojim kvalitetnim predstavama u više navrata nastupali u prostorima Kluba te na Radio Varteksu za koji su pripremali posebne programe. ${ }^{21}$ Spomenutoj svečanosti prisustvovali su brojni uzvanici među kojima i najviši dužnosnici gradske, općinske i republičke razine. ${ }^{22}$

15 "Poklon omladini Gimnazije", Varaždinske vijesti, br. 49 od 9. XII. 1965., str. 2.

16 "Polugodišnji izvještaj rada OK V3 Gimnazije Varaždin", Gimnazijalac, br. 1 od 1. veljače 1966.

17 U okviru programa održani su i sportski susreti dviju škola koji su obuhvatili natjecanja iz atletike, nogometa i rukometa. Varaždinci su ulogu domaćina odigrali besprijekorno, goste su dočekivali na kolodvoru te su ih ugostili u svojim domovima. Želeći da se u Varaždinu osjećaju što ugodnije, Kragujevčane su vodili po Varaždinu, pripovijedali im povijest grada i upoznavali ih s njegovom kulturom (op. a.).

18 "Vrijedan smjeh", Varaždinske vijesti, br. 1192 od 28. IX. 1967., str. 7.

19 "Među najboljima u zemlji", Varaždinske vijesti, 14. IV. 1966. br. 1115, str. 6.

21 "Smijeh u đačkim klupama", Varaždinske vijesti, br. 41 od 14. X. 1967., str. 105.

22 "Mladost Gimnaziji", Varaždinske vijesti, br. 2 od 19. 1. 1967., str. 1. 
U Gimnaziji je tim povodom bila priređena i prigodna izložba koja je predstavila rad u školi. ${ }^{23}$

U ovom razdoblju Klub je poticao likovni, glazbeni, literarni i scenski rad, ne samo u Gimnaziji, već i u Varaždinu. U Klubu su nastupali kasnije poznati umjetnici poput renomiranog akademskog slikara i kipara Nenada Opačića ${ }^{24}$ i budućeg čuvenog violinista Jože Haluze. ${ }^{25}$ Uz već spomenute Potepuhe, Dramski studijo varaždinske Gimnazije priređivao je brojne priredbe organizirane u Gimnaziji, često u prostoru Kluba, ali i u gradu. Okupljajući članstvo koje je prvenstveno pripadalo generacijama koje su maturirale u razdoblju 1967.-70., predvođeni kasnije priznatim scenskim umjetnicima Zlatkom Vitezom i Slavkom Brankovom, izvodili su razne prigodne programe, večeri poezije, kao i nekoliko kraćih dramskih djela. Recitatorska grupa je krajem šk. g. 1966./67. priredila literarnu večer koja se pokazala kao uspjela književna manifestacija. ${ }^{26}$ Izvrsni recitatori, učenici Zlatko Vitez, Slavko Brankov, Josip Čelar i Zvonko Kušter pružili su prisutnima recital visokih umjetničkih kvaliteta. Prema riječima kritike: "svaka izgovorena riječ bila je vrijedno dostignuće, pri čemu posebno treba istaknuti izražajno, decentno recitiranje Josipa Čelara te originalan stvaralački pristup tekstu Slavka Brankova". ${ }^{27}$ U posebnom dodatku programa Brankov je interpretirao Ženidbu Grigorija Korsa te jedan Puškinov tekst na ruskom.

Među scenskim priredbama ostvarenim tijekom sljedeće godine bila je posebno zapažena uspjela izvedba Nušićeve Vlasti. ${ }^{28}$ Kako su se na festivalu Susreti mladih u Đurđevcu uspješno predstavili s dramom Panika Željka Falouta, članovi Dramskog studija su je 14. rujna 1968., odlučili izvesti u Klubu, obilježavajući početak školske godine. ${ }^{29} \mathrm{U}$ petak 22 studenoga 1968. u Klubu je u organizaciji Dramskog studija bila održana vrlo uspješna večer poezije Tina Ujevića. S mnogo umješnosti Slavko Brankov je brojnom slušateljstvu prenio Ujevićevu pjesničku riječ, a osvrt na njegov rad i život dao je među varaždinskom mladeži pjesnik

\footnotetext{
23 "Prigodna priredba", Varaždinske vijesti, br. 1 od 12. 1. 1967., str. 5.

24 Razgovor autora s gospodinom Opačićem od 23. III. 2020. i pismo gospodina Krešimira Ferinca autoru od 17. VIII. 2018.

25 Razgovor i pismo gospodina Jože Haluze autoru od 12. II. 2020.

26 Priređivači su odabrali 20-ak pjesama iz opsežnih zbirki Vladimira Županića te su ih predstavili okupljenom slušateljstvu, koje je bilo iznenađeno zanimljivošću stihova te kvalitetnim i svježim scenskim prezentiranjem tekstova (op. a.).

27 “Uspjela književna manifestacija", Varaždinske vijesti, br. 23 od 8. VI. 1967., str. 5.

28 "Oživjeti studio", Varaždinske vijesti, br. 35 od 11. IX. 1968., str. 4.

29 Varaždinske vijesti, br. 35 od 11. IX. 1968., str. 4.
} 
Vladimir Županić. ${ }^{30}$ No kad su maturirale generacije koje su do tada bile nositelji aktivnosti Kluba, njegova je djelatnost počela zamirati. Od starijih entuzijasta Dramskog studija u školi je ostao još samo Slavko Brankov, koji je u međuvremenu postao maturant. Učenici prvih razreda pokušali su oživjeti rad Dramskog studija. Željko Kušter u tu je svrhu napisao dramu Izdisaj koju su članovi njihove dramske grupe uvježbali u prostorima Kluba gdje je, prema riječima jednog od sudionika, bila upriličena samo jedna njena izvedba. ${ }^{31}$ Važno je naglasiti kako su organizatori, kreatori i izvođači ovog bogatog kulturno-umjetničkog rada prvenstveno bili učenici Gimnazije.

Subotnje plesne večeri u početku su bile vrlo uspješne i masovno posjećivane. Posebno ilustrativna bila je plesna večer održana 4. ožujka 1967. godine, na kojoj je nastupio tada popularni varaždinski vokalno instrumentalni sastav Dijamanti. Posjećenost i nastala gužva doveli su do poziva policiji kako bi se odstranilo one koji nisu učenici Gimnazije. ${ }^{32}$ Bilo je primijećeno da pucaju stropovi u katu ispod prostorije Kluba tako da se slične svirke nisu više ponavljale. Podna konstrukcija nekadašnje crtaone nije mogla podnijeti opterećenja modernih plesnih ritmova pa su se sudionici morali ograničiti na lagane plesove. ${ }^{33}$ Plesne večeri su stoga s vremenom izgubile svoju draž. Sve je to pridonijelo gašenju aktivnosti pa tijekom šk. g. 1969./70., Klub formalno više nije djelovao. ${ }^{34}$

\section{NOVI UZLET U NOVIM PROSTORIMA}

U periodu 1971.-1973. godine provedena je adaptacija gimnazijske zgrade, što nije bilo poduzimano još od Drugog svjetskog rata. ${ }^{35} \mathrm{U}$ ovakvim okolnostima šk. g. 1971./72. bilo je inicijativa da se stari, neodgovarajući prostor Kluba pokuša iskoristiti kao slušaonica ozbiljne glazbe. Gimnazijsko Kulturno-zabav-

\footnotetext{
30 "Veće Tinove poezije", Varaždinske vijesti, br. 46 od 27. XI. 1968., str. 7.

31 Pismo Željka Pilipovića jednog od sudionika u radu Kluba autoru 5. XII. 2017.

32 Pismo Krešimira Ferinca autoru od 17. VIII. 2018.

33 Pismo Andreja Dermola, jednog od sudionika u osnivanju Kluba autoru.

34 Pismo Željka Pilipovića jednog od sudionika u radu Kluba autoru 5. XII. 2017.

35 Tom prilikom je umjesto starih kalijevih peći u zgradu uvedeno centralno grijanje, u podrumu je napravljena kotlovnica, izmijenjene su dotrajale električne instalacije i uvedena kvalitetnija rasvjeta, a dotadašnji daščani podovi su zamijenjeni lakiranim parketom. Uređeni su sanitarni čvorovi, stubišta i hodnici na kojima su postavljene vješalice i sanduci za cipele. Tom prilikom bila je povećana i uređena zbornica, nanovo su opremljeni pojedini učionički i kabinetski prostori. Bivša crtaona tj. dotadašnji prostor Kluba bio je prenamijenjen. Dio njegovog prostora bio je iskorišten za potrebe povijesnog kabineta, dok je u ugaonom dijelu drugog kata bio opremljen kabinet za nastavu zemljopisa (op. a.).
} 
no povjerenstvo prihvatilo je prijedlog varaždinske Muzičke omladine da se Klub za njene potrebe koristi dva puta tjedno. ${ }^{36}$ No ideja je ostala samo u razmatranju jer je tijekom spomenutih radova bivši prostor Kluba bio prenamijenjen. Kako u podrumu više nije skladišten ogrjev, on je, na prijedlog samih učenika, adaptiran i uređen kako bi se u njega preselio učenički klub. ${ }^{37}$ Prijedlog je s odobravanjem prihvaćen i na višim instancama, koje su ozbiljno tragale za osmišljenim prostorom namijenjenim mladeži.

U podrumskom dijelu južnog krila školske zgrade uređen je prostor dvoranskog tipa koji je, uz veliku dvoranu s pozornicom, sadržavao poseban prostor za potrebe vodstva Kluba, skladište i sanitarni čvor. Do njega su vodila dva odvojena ulaza sa stubištima, smještena u gimnazijskom dvorištu. ${ }^{38}$ Kako se ovdje planiralo održavanje disco-večeri, uzduž stubišta postavljene su vješalice s brojevima, kao improvizirana garderoba za sudionike održavanih programa. Pri izvođenju radova dobrovoljno su sudjelovali učenici, ${ }^{39}$ a njihov kraj nestrpljivo su čekali sudionici brojnih gimnazijskih slobodnih aktivnosti, očekujući bolje uvjete za rad. ${ }^{40}$ Svečano otvaranje novih prostora Omladinskog kluba V3 i knjižnice s čitaonicom obilježeno je skromnom svečanošću kojoj su početkom svibnja 1973., prisustvovali brojni gosti i bivši učenici koji su tom prilikom obišli novouređene prostore. ${ }^{41}$ U njima je tom prilikom otvorena izložba učeničkih radova. ${ }^{42}$ Preuređenu Gimnaziju je tjedan dana kasnije u okviru svojeg dvodnevnog posjeta varaždinskom kraju, obišla pjesnikinja Desanka Maksimović, autorica Krvave bajke, posjećujući i Klub nazvan po razredu V3 čija su stradanja opjevana u njenoj tragičnoj poe-

36 "Gimnazijski Klub V3 za Muzičku omladinu", Varaždinske vijesti, br. 38 od 2. X. 1971., str. 20.

37 "Među najboljima u Republici", Varaždinske vijesti, br. 7 od 19. II 1972., str. 5.

$38 \mathrm{U}$ podrumskom dijelu južnog krila zgrade bio je uređen prostor dvoranskog tipa u koji je moguć pristup kroz dva posebna ulaza smještena u dvorištu. Do njega su vodila dva odvojena stubišta. Ulaz i stubište bliži kolskom ulazu u dvorište, vodili su do posebne prostorije, približno 7,5×5 m, uređene za potrebe rukovodstva Kluba te do skladišnog prostora za stolice i pomagala. Kroz njega je, za sudionike i izvođače budućih programa, omogućen direktan pristup pozornici. Ulaz i stubište bliži kraju južnog krila zgrade vodili su u središnju dvoranu dimenzija $24 \times 7 \mathrm{~m}$ koja je zapremala gotovo čitav podrumski prostor ovog dijela zgrade. Na njenom završetku opremljen je sanitarni čvor, a pod dvorane izravnan je iskapanjem suvišne zemlje, izbetoniran i pokriven keramikom. Kako bi se onemogućilo ulijevanje oborinskih voda, žljebovi su povezani s kanalizacijom. Na njenom suprotnom kraju bližem ugaonom dijelu zgrade uređena je drvena pozornica koja je zapremala još dodatnih $7 \times 7 \mathrm{~m}$, podignuta za 30 -ak $\mathrm{cm}$ iznad razine poda (op. a.).

39 Pismo Željka Pilipovića jednog od sudionika u radu Kluba autoru 5. XII. 2017.

40 "Na startu", Varaždinske vijesti, br. 16 od 22. IV 1972., str. 15.

${ }^{41}$ Za preuređivanje zgrade utrošeno je više od 3400000 din., a inicijativa je potekla od samih omladinaca i bivših učenika (op. a.).

42 "Nove klupske prostorije", Varaždinske vijesti, br. 18 od 10. V. 1973., str. 24. 
mi. ${ }^{43}$ Kako je pregradnjom bivše crtaone, izgubljen jedini veći prostor potreban za odvijanje javnih manifestacija, planirano je da novouređeni Klub posluži i za održavanje javnih događanja, kulturno-zabavnih priredaba i rad grupa slobodnih aktivnosti. Tamo je primjerice, svečanom akademijom obilježen Dan žena 1974. godine. $^{44}$

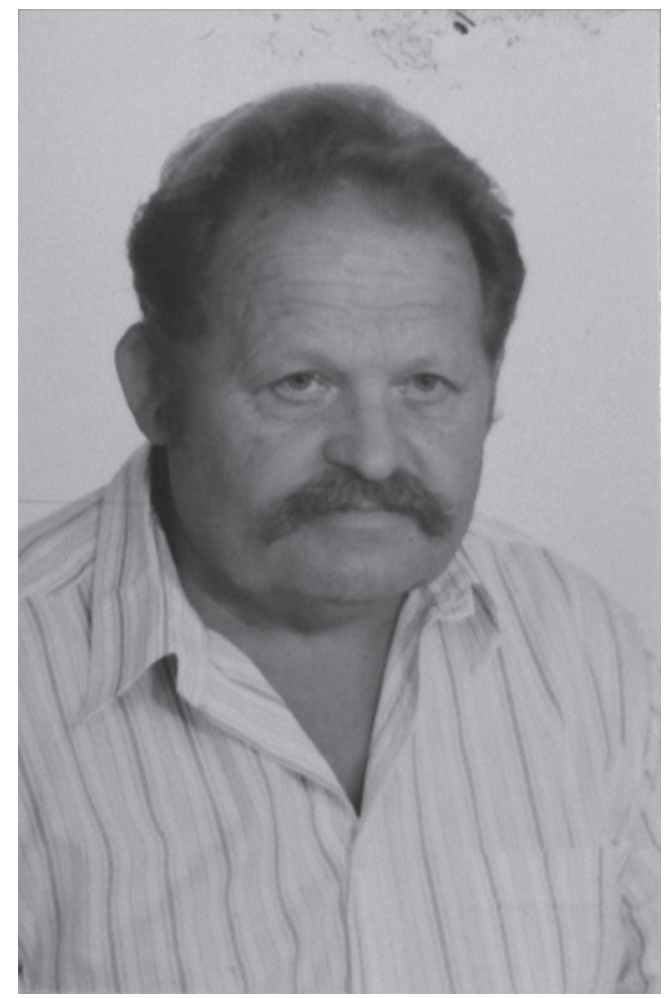

Slika 1. Profesor Franjo Bračko, dugogodišnji voditelj Kluba

Uz profesora Bračka koji je i nadalje bio za njega zadužen od Nastavničkog vijeća, brigu za funkcioniranje Kluba, vodilo je rukovodstvo službeno zvano Uprava Kluba. Ovisno o godini, činilo ju je 20-ak do 50-ak članova, popunjavanih svake godine novim članovima iz prvih razreda prema preporuci starijih. Bilo je bitno da su spremni marljivo raditi, uložiti svoje slobodno vrijeme i vještine potrebne

43 "Dirljivo i toplo", Varaždinske vijesti, br. 19 od 17. V. 1973., str. 10.

44 "Gimnazijalac", br. 9, travanj-svibanj 1974., str. 2. 
za obavljanje konkretnih zadataka vezanih uz odvijanje pojedinih aktivnosti. Članovi su se, prema potrebama i vlastitim sklonostima, opredjeljivali za davanje podrške određenim djelatnostima. Dogovarali su dežurstva, rukovali potrebnom tehnikom, postavljali i uklanjali stolice i ostale rekvizite, čistili i održavali prostore i vodili računa o prikupljenom novcu. ${ }^{45}$

Ključna aktivnost Kluba na području zabave bilo je priređivanje disco-večeri, povodom čega je proljetni broj Gimnazijalca iz 1973., uputio promidžbeni poziv. ${ }^{46}$ Plesne večeri su redovito priređivane subotom, ili povodom prigodnih događanja u školi. Posjećivalo ih je do 300 mladih, ne samo učenika Gimnazije, već i dobar dio mladih našeg grada. Ulaznina je naplaćivana, no nije dozvoljeno pušenje ni unošenje alkohola, za što se redovito brinulo po nekoliko članova Uprave kluba koja je preuzimala i odgovornost za red, dežurstva i prikupljeni novac. ${ }^{47}$ To je bio jedan od najunosnijih, a povremeno $i$ jedini izvor financiranja za sve ostale klupske aktivnosti. Prvi zvučnici i pojačala nabavljani su vlastitim sredstvima ili donacijama, dok se u nabavku gramofonskih ploča išlo i u Graz. ${ }^{48}$ Odabir i reprodukciju glazbe u početku su dobrovoljno obavljali članovi Kluba, što je kao obaveza tijekom svake subotnje večeri, za njih postalo veliko opterećenje. Kako bi se, uz ugodan ambijent osiguralo i dobro ozračje, od šk. g. 1976./77., za vođenje disco-večeri profesionalno je angažiran poznati čakovečki disc-jockey, Dragutin Molnar Čarli. ${ }^{49}$ Neposrednom konverzacijom s mladima i kvalitetnom opremom, ubrzo je stekao simpatije i podigao kvalitetu disco-večeri. U početku je njihovo trajanje bilo ograničeno do $21 \mathrm{~h}$, no kasnije se sve više produživalo. Po završetku plesa, za to zaduženi članovi su redovito, često i tijekom nedjeljnog jutra, obavljali čišćenje kako bi početkom novog radnog tjedna klupski prostor bio pripremljen za ostale djelatnosti i na raspolaganju ostalim korisnicima.

$\mathrm{Na}$ odgojno-obrazovnom planu priređivana su predavanja i susreti sa sudionicima u političkom i javnom životu, pri čemu se nastojalo pratiti društvenopolitičke trendove, ali i trenutne preokupacije mladeži. Odluke o izboru tema i predavača donošene su tek nakon svestrane diskusije. U Klubu su se s mladima susretali revolucionari poput Karla Mrazovića-Gašpara i Pavla Gregorića koji je

\footnotetext{
45 Sjećanja profesora Franje Bračka iz razgovora s autorom 12. XI. 2019. godine.

46 Gimnazijalac, br. 7, ožujak-travanj 1973., str. 7.

47 Nakon svake disco-večeri ili kino-predstave, ubrani prihod se pohranjivalo u sef smješten iza slike u bočnom spremištu s jakim metalnim vratima, smještenoj uz stubište prema pozornici. Članovi Uprave kluba izabrali bi blagajnika i osobe koje su, uz voditelja imale pristup sefu (op. a.).

48 Pismo Mirne Rukavina-Bakšaj, sudionice u radu Kluba autoru 2. XII. 2019.

49 "Dragutin Molnar Čarli", Gimnazijalac, br. 18, studeni 1977., str. 9.
} 
na Dan SKOJ-a 1974., održao predavanje Moji susreti s drugom Titom. ${ }^{50}$ Zahvaljujući dobroj suradnji s varaždinskim PD Ravna Gora, učenici su krajem 1975./76. godine pratili predavanje Spilje u našoj Republici, koje je, uz dijapozitive u boji, održao mr. Srećko Božićević iz Zagreba. ${ }^{51}$

U okviru Kluba djelovala je kino-grupa koja je imala zadatak osigurati redovite tjedne projekcije odgojno-obrazovnih, mladeži zabavnih filmova. To je podrazumijevalo brigu od izbora, nabave, projiciranja, održavanja opreme, ubiranja ulaznine i dežuranja za vrijeme projekcije. Izbor filmova koji će se prikazivati obično su početkom godine izvršili razredni kulturni referenti. ${ }^{52} \mathrm{~S}$ distributerom je na godinu dana potpisivan ugovor, a za to zaduženi članovi Kino-grupe redovito su film preuzimali na pošti. Povremeno su uspostavljali i suradnju s JNA pa su projicirani i filmovi s vojnom tematikom, a školski kino-klub također je vlastita ostvarenja predstavljao u klupskom prostoru. ${ }^{53}$ Projekcije su, uz simboličnu ulazninu, priređivane jednom tjedno. No zanimanje za ovu djelatnost nije ispunilo očekivanja i s vremenom je redovito projiciranje filmova zamrlo svodeći se samo na prigodne projekcije, ovisno o potrebi. Kako bi se pripremili za nadolazeći maturalni ples, učenici maturalnih razreda su u Klubu počeli organizirati Školu plesa koju je krajem 1974. posjetila ekipa RTV Zagreb, snimajući njene aktivnosti i razgovarajući s polaznicima. ${ }^{54}$ Takva plesna škola i ubuduće je organizirana, a njezino vođenje najčešće su preuzimali profesori tjelesnog odgoja.

U novouređenom klupskom prostoru često su se odvijale svečanosti i aktivnosti vezane uz djelovanje škole. Kao rezultat višegodišnje suradnje škole i Komunalnog poduzeća Varkom, 9. veljače 1975. u Klubu je održana svečana predaja poklona poduzeća Varkom Gimnaziji Varaždin. ${ }^{55}$ Gimnazijalci su u okviru svog obaveznog proizvodnog rada radili na uređivanju cesta u Varaždinu i okolici, a poduzeće je pomoglo pri adaptaciji školske zgrade i uređenju dvorišta. ${ }^{56}$ Varkom je Klubu namjeravao pomoći pri nabavi novog pojačala za potrebe organiziranja subotnjih disco-večeri. ${ }^{57} \mathrm{U}$ Klubu su se povremeno održavali sastanci, sku-

\footnotetext{
50 "Posjet Dr. Pavla Gregorića Gimnaziji", Gimnazijalac, br. 10, listopad-studeni 1974., str. 2.

56 Na spomenutoj svečanosti školi su poklonjena 2 TV aparata, veliki i portabl, 2 magnetofona, 2 dijaprojektora i grafoskop, što je pridonijelo unapređivanju nastave. U ime poduzeća poklone su predali direktor Dragutin Pšak, te predsjednik radničkog savjeta Željko Martinez (op. a.).

57 "Gimnazijalci na proizvodnom radu", Varaždinske vijesti, br. 46 od 18. XI. 1976., str. 12.
} 
povi i manifestacije, organizacija i udruga koje su djelovale unutar škole. Učenici i profesori Gimnazije su 1976. obilježili Dan mladosti proslavom 30-godišnjice gimnazijskog sportskog društva Srednjoškolac. Tim je povodom u Klubu bila postavljena izložba osvojenih trofeja. ${ }^{58}$ A 13. listopada 1976., održana je tematska konferencija SSO, na kojoj su predloženi kandidati za Savjet škole iz redova Omladinske organizacije, ${ }^{59}$ a gost konferencije, dr. Josip Martinčević podnio je opširno izlaganje o Zakonu o udruženom radu.

Novouređeni klupski prostor privlačio je pozornost pa su se povremeno u njemu odvijali programi koji neposredno nisu imali veze s Gimnazijom i njenim polaznicima. Premda je službeno otvaranje novog Kluba uslijedilo gotovo dva mjeseca kasnije, prvi službeni program koji je u njemu upriličen bio je Plenum o preradi Zakona o srednjoškolskom obrazovanju, održan 16. ožujka 1973. godine. ${ }^{60} \mathrm{U}$ prvim godinama njenog rada u Klubu je redovito djelovala omladinska politička škola SK općine Varaždin. ${ }^{61}$ Svaki njezin ciklus završio bi svečanom podjelom diploma polaznicima, koja je također priređivana u prostoru Kluba. ${ }^{62} \mathrm{U}$ petak 28. ožujka 1975. u Klubu je održana osnivačka skupština podružnice Društva industrijskih pedagoga Jugoslavije. ${ }^{63}$

Početkom 1976./77. godine Varaždinski su gimnazijalci svečano obilježili dva svoja jubileja. U četvrtak 21. listopada 1976., na obljetnicu kragujevačke tragedije oni su proslavili Dan škole i 10-godišnjicu uspješnog djelovanja Omladinskog kluba V3. Tom prilikom bio je priređen prigodan kulturno-umjetnički program i brojna sportska natjecanja, dok je Klub među učenicima organizirao uspjeli literarni natječaj na temu: Kragujevac - 21. listopada $1941 .{ }^{64}$ Proslavi je kao poseban gost prisustvovala renomirana glumica Mira Banjac u pratnji novinara zagrebačke revije Studio. Njeni reporteri su pratili program proslave, a njegov su prikaz s popratnim foto-materijalom objavili u svojoj reviji. ${ }^{65} \mathrm{U}$ okviru programa Mira Banjac je okupljenima recitirala nekoliko poema s rodoljubnom i ratnom tematikom, pridonoseći ozračju vlastitim umjetničkim izričajem. Zajedno s profesorima i učenicima pratila je TV-prijenos Velikog školskog sata u Kragujevcu. Uslijedio je

\footnotetext{
58 "U znaku mladosti i sporta", Varaždinske vijesti, br. 22 od 3. VI. 1976., str. 1.

59 "Omladina Gimnazije o ZUR-u", Varaždinske vijesti, br. 42 od 21. X. 1976., str. 2.

60 "Klub je otvoren", Gimnazijalac, br. 7, ožujak-travanj 1973., str. 3.

61 Počela je djelovati 23. siječnja 1974., s namjerom da osigura sustavnu izobrazbu postojećeg i novog mladog političkog kadra.

62 "Završila radom Omladinska politička škola Gimnazije", Varaždinske vijesti, br. 14 od 8. IV. 1976., str. 4.

63 "Osnovana podružnica društva industrijskih pedagoga", Varaždinske vijesti, br. 13 od 3. IV. 1975., str. 7.

64 "Učenici varaždinske Gimnazije proslavili Dan škole", Varaždinske vijesti, br. 43 od 28. X. 1976., str. 12.

65 Varaždinski V3, Studio br. 656, str. 23-25.
} 
razgovor i druženje tijekom kojeg su je članovi Uprave Kluba zamolili za još jedan susret. ${ }^{66} \mathrm{Na}$ poziv Kluba, ona je već sljedećeg tjedna, točnije 30 . listopada, ponovo gostovala u Varaždinu, a kako je zanimanje za njeno gostovanje bilo izuzetno, zakupljena je i potpuno ispunjena kazališna dvorana. Čuvena glumica u prvom dijelu programa predstavila je svoj životni i glumački put te općenito glumački poziv. Interpretirala je ostvarenja pojedinih vojvođanskih pjesnika, naglašavajući i na taj način vlastito porijeklo. Potom se prisutnima predstavila nizom monologa, a na kraju je izvela odlomak iz svoje, vrlo uspješne, monodrame Ljubica - prvo lice množine. ${ }^{67}$

\section{USPON PREMA VRHUNCU DJELOVANJA}

Sredinom 70-ih godina u Omladinskom klubu V3 bio je dobro razrađen i ustaljen način upravljanja i provođenja aktivnosti. Odlučivalo se demokratski, iznošenjem prijedloga i dogovaranjem na redovito održavanim sastancima članstva Uprave kluba, dok je voditelj, sveprisutni prof. Bračko, svojim autoritetom osiguravao stabilnost $\mathrm{u}$ radu. $\mathrm{U}$ čitavom ovom periodu redovito su priređivane izuzetno posjećene subotnje disco-večeri čiji je prihod predstavljao najizdašniji izvor prihoda. O ubiranju, raspodjeli i korištenju ovih sredstava samostalno je odlučivalo članstvo Uprave kluba. S mnogo uspjeha su organizirano održavana predavanja, priređivane projekcije filmova, disco-večeri, izložbe, gostovanja i susreti s poznatim osobama. Povodom 30-te obljetnice pobjede nad fašizmom, član savjeta Federacije, dr. Josip Hrnčević je 17. studenoga 1975. održao predavanje o razvoju radničkog pokreta i pripremama za ustanak na sjeverozapadu $\mathrm{Hr}$ vatske. ${ }^{68}$ No osim poznatih revolucionara u Klubu su gostovali i predavači raznih zanimanja i preokupacija poput svjetskog putnika Tibora Sekelja, koji je u suorganizaciji s Esperantskim društvom Varaždin, potkraj 1975. održao predavanje s dijapozitivima o svojim putovanjima i boravku među prastanovnicima Amazonije koji nisu kontaktirali s civilizacijom. ${ }^{69}$ Premda je Klub mogao primiti oko 200 slušatelja, zanimanje za ovo predavanje bilo je daleko veće i sigurno bi bio ispunjen i veći prostor kakve se za atraktivnije goste povremeno zakupljivalo. Zbog velikog zanimanja legendarni rock-glazbenik Drago Mlinarec je na poziv Kluba u četvrtak

66 Varaždinski V3, Studio br. 656, str. 23-25.

67 "Naša gošća Mira Banjac", Gimnazijalac, br. 15, studeni 1976., str. 8.

68 "Posjet dr. Hrnčevića Gimnaziji", Gimnazijalac, br. 13, svibanj 1976., str. 3.

69 Sjećanje autora. 
2. prosinca 1975., održao izuzetno uspješan koncert u koncertnoj dvorani. ${ }^{70} \mathrm{Na}$ stupi i gostovanja nastavili su se nizati pa su, posredstvom planinarske sekcije u siječnju 1976. u Klubu gostovali sudionici jugoslavenske alpinističke ekspedicije u Himalaji. Razgovor s vođom ekspedicije Alešom Kunaverom vodili su članovi planinarske sekcije. Ujesen iste godine uslijedio je kvalitetan i izuzetno dobro prihvaćen zajednički nastup i literarna večer varaždinskog pjesnika Vladimira Županića i kantautora Dragutina Novakovića-Šarlija. ${ }^{71}$ Glavni urednik NIŠP Vjesnik i počasni konzul Kraljevine Norveške u Jugoslaviji Željko Takač 17. studenoga 1976. održao je predavanje SAS-om preko polarnog kruga. ${ }^{72}$

Uz brojna zvučna imena, nositelji pojedinih programa bili su povremeno članovi Kluba i učenici. Učenica Božica Pažur, kao nositelj literarne večeri, recitirala je svoje pjesme, dok je Davorin Zver, član planinarske sekcije slušateljstvo uz dijapozitive proveo Velebitskom transverzalom..$^{73} \mathrm{Na}$ kraju godine Klub je obično za članove organizirao izlet pa su 1975./76., članovi Uprave kluba proveli tri nezaboravna dana na Ivančici. ${ }^{74}$ Kako bi takva logorovanja bila ugodnija, nabavljena je kvalitetna logorska oprema s agregatom vođena kao inventar kabineta obrane i zaštite korištena za vježbe u okviru tog predmeta. ${ }^{75}$

Tijekom svog boravka u Varaždinu u ožujku 1977., predsjednik SSO Hrvatske, Željko Mažar bio je gost gimnazijalaca s kojima je u Klubu razgovarao o tada aktualnoj reformi školstva i ulozi SSO u obrazovnom procesu. ${ }^{76}$ Krajem 1976./77. u Klubu je gostovala novinarka i urednica NIŠRO Vjesnik iz Zagreba, Dara Janeković i održala predavanje o situaciji u Kini. Predavanju je prisustvovalo 200 učenika, popraćeno je dijapozitivima i filmom te je pobudilo veliko zanimanje i brojna pitanja prisutnih. ${ }^{77}$ Kao gosti Kluba u ovom su se periodu s gimnazijalcima družili: ing. Zlatko Smerke, kantautor Arsen Dedić, dr Josip Kotnik, karikaturista Oto Reisinger, pjesnik Enes Kišević, glumac Fabijan Šovagović i još poneko ime iz svijeta književnosti, kazališta, filma i sporta. ${ }^{78} \mathrm{U}$ klupskim programima nisu bili zaboravlj

\footnotetext{
70 "Naš gost Drago Mlinarec", Gimnazijalac, br. 13, svibanj 1976., str. 6.

71 Gimnazijalac, br. 15, studeni 1976., str. 7.

72 "Željko Takač u Gimnaziji", Gimnazijalac, br. 15, studeni 1976., str. 5.

73 "Upoznajmo Klub V3", Gimnazijalac, br. 13, svibanj 1976., str. 4.

74 "Klub V3 na Ivančici", Gimnazijalac, br. 15, studeni 1976., str. 8.

75 Sjećanja profesora Franje Bračka iz razgovora s autorom 12. XI. 2019. godine.

76 Varaždinske vijesti, br. 10 od 17. III. 1977., str. 3.

77 Varaždinske vijesti, br. 24 od 23. VI. 1977., str. 2.

78 Profesor Bračko se posebno sjeća nastupa glumca Fabijana Šovagovića koji se, izvodeći pojedine točke, služio rekvizitima pa je na prisutne poseban dojam ostavilo pucanje bičem koje je zvučno odjekivalo podrumskim prostorom Kluba (op. a.).
} 
eni ni uspješni domaći sportaši poput atletičara Atletskog kluba „Sloboda“Željka Knapića i Dijane Sokač. ${ }^{79}$ Početkom 1979./80., predavač na politološkom fakultetu Dušan Bilandžić u Klubu je održao predavanje 60 godina SKOJ-a, a tijekom godine priređena su i druga. Vjekoslav Grabarić izlagao je $O$ oslobodilačkim pokretima na jugu Afrike. ${ }^{80} \mathrm{U}$ suradnji s varaždinskim esperantistima, organizirano je zapaženo predavanje prof. Spomenke Štimec Putopis po Arizoni.$^{81}$ Logožar Robert predavao je $O$ razvoju Sunčevog sistema i svemira, a kao predavači su nastupili još dr. Pavao Brajša i pjesnikinja Katica Pšak. ${ }^{82}$ Klub je ugostio glumca Čedu Vujića koji je za okupljene izveo svoju monodramu koju je šansonjer Dragutin Novaković-Šarli popratio svojim šansonama. ${ }^{83}$ Troškove ovih programa Klub je pokrivao vlastitim prihodima, a sudionike programa u Varaždin je često osobno, dovozio prof. Bračko. U okviru Glazbene slušaonice u goste su pozivani sastavi i lokalne grupe poput Porodičnog stabla, Impulsa i Jan Amosa koji su u Klubu povremeno priređivali koncerte. ${ }^{84}$

U prostoru Kluba nadalje su obilježavana značajna događanja i održavane prigodne manifestacije. Priređivane su svečane akademije povodom Dana Kluba, Dana Republike, Dana Armije i Dana žena. Na Dan žena obično su priređivane izložbe ručnih radova. ${ }^{85}$ Godine 1980 . cijeloga tjedna bila je otvorena izložba ručnih radova žena 1. mjesne zajednice i učenica Gimnazije. ${ }^{86}$ Povremeno su se održavala raznovrsna natjecanja i kvizovi. U Kvizu znanja susretale bi se ekipe škola, fakulteta, omladinskih organizacija i mjesnih zajednica. ${ }^{87}$ Godinama su priređivana natjecanja zabavnog karaktera poput natjecanja pod nazivom Tko umije - njemu dvije i tradicionalni karnevalski ples pod maskama. ${ }^{88} \mathrm{U}$ organizaciji Kluba redovito su priređivane izložbe foto-materijala s učeničkih maturalnih

\footnotetext{
79 Pismo Dinke Žulić, rođene Bertapelle članice Uprave Kluba autoru.

80 "Izvještaj o radu Omladinskog kluba V3 SC "Gabriel Santo" Varaždin za školsku godinu 1979./80.", Omladinski list List Saveza Socijalističke Omladine SŠC “Gabriel Santo" Varaždin, br. 25, travanj 1980. str. 6.

81 "Brojne aktivnosti varaždinskih esperantista", Varaždinske vijesti, br. 8 od 28. II. 1980., str. 12.

82 "Izvještaj o radu Omladinskog kluba V3 SC "Gabriel Santo" Varaždin za školsku godinu 1979./80.", Omladinski list List Saveza Socijalističke Omladine SŠC "Gabriel Santo" Varaždin, br. 25, travanj 1980., str. 6.

83 Isto.

84 Isto.

85 "Omladinski klub V3 ponos varaždinske Gimnazije", Varaždinske vijesti, br. 6 od 16. II. 1978., str. 12.

86 "Ženi radnici majci", Varaždinske vijesti, br. 10 od 13. III. 1980., str. 2.

87 U ponedjeljak 16. veljače 1976. godine u Omladinskom klubu V3 bio je održan susret ekipa Gimnazije i varaždinskog Fakulteta organizacije i informatike.

88 Varaždinske vijesti, br. 6 od 16. II. 1978., str. 12.
} 
ekskurzija ili s organiziranih logorovanja članova Uprave Kluba. One su budile zanimanje samih sudionika i posjetitelja. No povremeno su postavljane i autorske izložbe. Priređujući svoju drugu samostalnu izložbu sportske fotografije, novinar varaždinskog IP Centra Ivica Vukotić je u studenom 1980., kao izložbeni prostor izabrao i prostor Kluba. ${ }^{89} \mathrm{U}$ prosincu iste godine mladež je u Klubu priredila Izložbu učeničkih hobija. ${ }^{90} \mathrm{Na} 10$-ak panoa i par improviziranih vitrina izloženo je sve što učenici skupljaju. ${ }^{91}$ Premda bez kataloga i ambicija da ostvari visoke vrijednosne domete, izložba se pokazala kao izuzetno zanimljiva i poticajna.
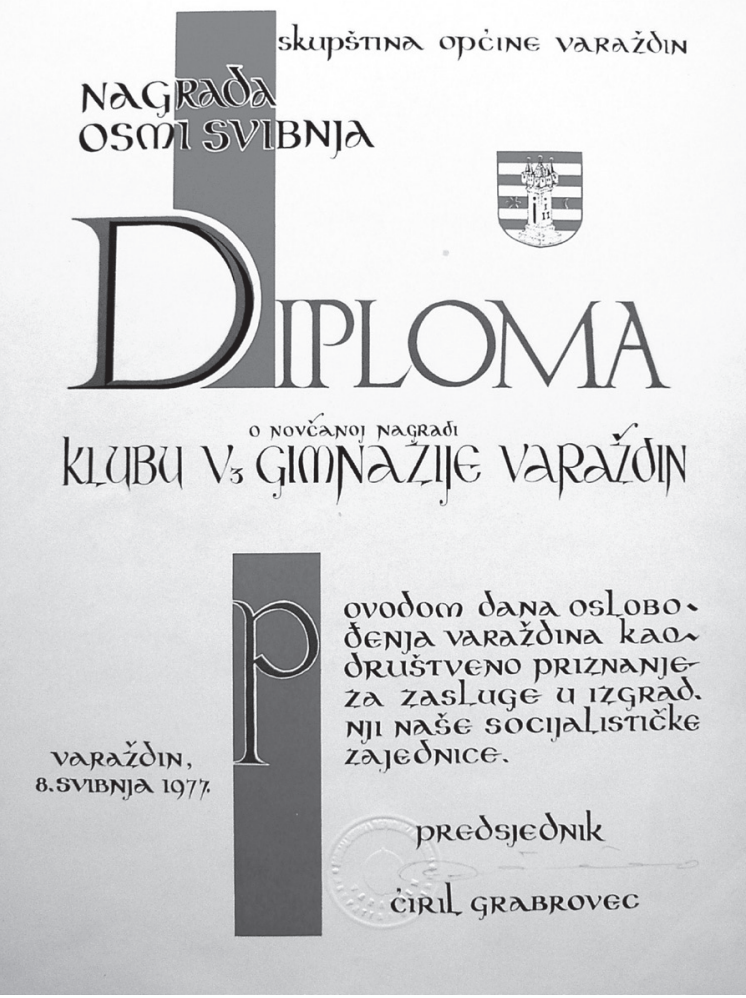

Slika 2. Omladinski klub V3 je za svoj rad dobivao nagrade i priznanja

89 Tom prilikom bilo je izloženo ukupno 57 njegovih crno-bijelih fotografija izložbenog formata.

90 "Luda mladenačka izložba", Varaždinske vijesti, br. 50 od 18. XII. 1980., str. 10.

91 Bilo je tu salveta, razglednica, značaka, kutija šibica, šećera za kavu u vrećicama i kockama, maraka, kalendara, lutaka i naljepnica (op. a.). 
Prostor Kluba nadalje je bio zanimljiv i široj zajednici. Zahvaljujući tome krajem ožujka 1978. pod stručnim vodstvom psihijatra dr. Pavla Brajše, u Klubu je održan trodnevni seminar iz predbračne, bračne i obiteljske problematike. ${ }^{92} \mathrm{Na}$ seminar se odazvalo stotinjak socijalnih radnika i drugih stručnjaka, stručnih timova centara za socijalni rad Varaždinske regije, ali i iz drugih krajeva Hrvatske i Slovenije. Odaziv je bio daleko veći nego se očekivalo, premda je bio organiziran na bazi samofinanciranja. ${ }^{93}$ Zatim će 26 . i 27. siječnja 1979. Društvo za uzgoj $i$ zaštitu golubova, zečeva i ukrasne peradi u Klubu prirediti međugradsku izložbu golubova. ${ }^{94}$ Kako je bilo zastupljeno 40 -ak vrsta golubova i ukrasne peradi, izazvala je zanimanje ne samo uzgajivača, nego učenika i građanstva, tim više jer je bila organizirana i prigodna prodaja golubova. ${ }^{95}$

\section{DJELOVANJE KLUBA POČETKOM OSAMDESETIH GODINA}

Sredinom 70-ih godina u Hrvatskoj je provedena obrazovna reforma koja je nastojala ukloniti postojeću podjelu na škole koje polaznike osposobljavaju za radnička zanimanja i na škole koje ih pripremaju isključivo za studij. Novi obrazovni sustav trebao je istodobno pripremati polaznike za visokoškolsko obrazovanje i za uključivanje u radni proces. To je podrazumijevalo ukidanje gimnazija pa je uslijedila njihova transformacija u tzv. polivalentne odgojno-obrazovne centre za školovanje kadrova konkretnih zanimanja. Srednjoškolsko obrazovanje planirano je u 2 faze. Pripremna faza u trajanju od 2 godine obuhvaćala je tzv. zajedničke programske osnove, jezgru općeobrazovnih predmeta upotpunjenu sustavu ideološki važnim predmetima, ${ }^{96}$ dok su u završnoj fazi predviđene 1 do 2 godine usmjerenog obrazovanja. Nastavom u pojedinim usmjerenjima u ovoj fazi dominirale su skupine predmeta ključnih za obrazovanje u konkret-

92 Seminar su organizirali Društvo socijalnih radnika općina Ivanec, Ludbreg, Novi Marof i Varaždin i Republički Zavod za socijalni rad u Zagrebu. Ovo je ujedno bio i prvi seminar sa spomenutom problematikom priređen u Varaždinu (op. a.).

93 "Održan uspjeli seminar o predbračnoj, bračnoj i obiteljskoj problematici", Varaždinske vijesti, br. 12 od 30. III. 1978., str. 11.

94 "Golubarska izložba", Varaždinske vijesti, br. 2 od 18. I. 1979., str. 12.

$95 \mathrm{Na}$ izložbi su sudjelovali golubari iz Subotice, Sombora, Novog Sada, Zagreba, Karlovca, Pule, Virovitice, Križevaca, Bjelovara Vukovara i iz Supetra na Braću te poznata sportska društva golubara iz Šapca, Čačka i Osijeka (op. a.).

96 To su primarno bili Osnova marksizma, Teorija i praksa samoupravnog socijalizma te Opčenarodna obrana i društvena samozaštita, a kako bi se stvorila osnova za približavanje radnoj praksi, u prvom razredu uvedeno je Proizvodno tehničko obrazovanje (op. a.). 
nom zanimanju. ${ }^{97}$ Godine 1975./76. i u I. razred varaždinske Gimnazije uveden je novi nastavni plan i program. ${ }^{98}$ Usporedo s reformom bila je razmatrana i ideja o promjeni naziva škole. Premda je u profesorskom zboru bilo protivljenja, na prijedlog Predsjedništva općinske Skupštine, ${ }^{99}$ odlukom Zbora radnika i Savjeta škole u ožujku 1978., prihvaćen je naziv Srednjoškolski centar „Gabriel Santo" Varaždin. Kako je obrazovala kadrove raznih struka i zanimanja, zanimanje za upis u ovu školu i dalje je raslo. U 80-im godinama upisivano je 10, a povremeno i do 12 razreda godišnje pa je njihov ukupan broj ponekad dosegao do 45 odjela i 1500 polaznika.

Prilagođavajući se novom sustavu samoupravljanja i pratećem zakonodavstvu, Omladinski klub V3 je 1979. upisan u Registar udruženja građana čime je, po Zakonu o udruženjima građana, stekao svojstvo pravne osobe ${ }^{100}$ pa je povodom toga izrađen novi Statut Kluba. ${ }^{101}$ Početkom 80 -ih godina u upravljanju Klubom nije bilo bitnih promjena. Njime je rukovodilo kolektivno tijelo Uprave kluba koje je obavljalo funkciju skupštine. ${ }^{102}$ Sastojalo se od nekoliko desetina članova koji su redovito održavali sastanke na kojima su odluke donosili dogovorno. Vodili su zapisnike, ${ }^{103}$ i izabirali predsjednika i ostale dužnosnike. ${ }^{104}$ Uglavnom su sami brinuli o uređenju, aktivnostima i održavanju prostora. Na prijedlog i u dogovoru s Upravom kluba, voditelja Kluba imenovao je Savjet Centra, ${ }^{105}$ a prof. Bračka je na toj dužnosti 1981. godine naslijedio prof. Darij Milković. ${ }^{106}$ Već tradicionalno priređivane subotnje disco-večeri postale su jedini relativno stalni izvor prihoda. $\mathrm{Na}$ izričit zahtjev novog voditelja, prihodi ubrani tijekom disco-večeri, polagani su na za tu svrhu otvoren račun. ${ }^{107}$ Kako su još uvijek bile jedina takva zabava u Varaždinu, među mladima su nadalje izazivale veliku pozornost te su prosječno

97 Gimnazijskih 380 godina, katalog izložbe u povijesnom odjelu GMV 12. X. - 19. XII. 2016., str. 29.

98 To je dovelo do njezinog preoblikovanja u polivalentni centar za obrazovanje kadra s područja odgoja i obrazovanja, uprave i birotehnike, matematike i informatike, tehnologije, kulture i ekonomije (op. a.).

99 Skupština općine Varaždin, broj 01 - 329/1 - 1978.

100 Općinski sekretarijat za unutarnje poslove Varaždin, Rješenje br. 02/4-Up.I-989 od 16. X. 1979.

101 Članak 5 Statut Omladinskog kluba V3 djelatnost Kluba definira kao organiziranje manifestacija, priredbi, predavanja i ostalih oblika aktivnosti kojima se dopunjuje i proširuje osnovna djelatnost škole zadovoljavanjem potrebe mladeži za sadržajima iz oblasti: društvenog života, znanosti, kulture, zabave, rekreacije i sporta, koje izlaze iz okvira redovne nastave (op. a.).

102 Statut Omladinskog kluba V3 iz 1979., čl. 15.

${ }^{103}$ Zapisnik sa konstituirajuće sjednice Omladinskog kluba V3 od 31. III. 1982.

104 Statut Omladinskog kluba V3 iz 1979., čl. 31.

105 "Odluka Savjeta Srednjoškolskog centra “Gabrijel Santo “Varaždin”, br. 1323/82 od 8. XI. 1982.

106 Razgovor profesora Milkovića s autorom u lipnju 2018. godine.

107 Isto. 
okupljale između 200 i 400 osoba. Premda je njihova uspješnost ovisila o fonoteci i umješnosti disc-jockeya,, Klub je i sam ulagao i brinuo o opremi, ${ }^{108}$ što je vidljivo iz popisa inventara iz listopada 1982. ${ }^{109}$

Od ostalih klupskih aktivnosti valja spomenuti priređivanje izložaba ručnih radova i posebno tradicionalnih izložaba fotografija s maturalnih putovanja, organiziranje Šašavijada popraćenih igrama spretnosti i natjecanjima u starim sportovima, gostovanja umjetnika, glazbenika, književnika i istaknutih osoba iz kulturnog, političkog i javnog života. Od poznatih glumačkih imena u ovom su periodu u Klubu sa svojim programima nastupili: Željko Vukmirica, Dubravko Sidor i Lada Kos, zatim Jure Kaštelan i ponovno novinarka Dara Janeković s temom Đošuini nasljednici. ${ }^{110}$ Klupski prostor se, prema potrebi i mogućnostima, pretvarao u pozornicu glazbenih, literarnih i plesnih priredaba. Kako su to bile aktivnosti koje su pridonosile odgoju i obrazovanju, vodstvo Centra i profesori su ih podržavali, pomažući u održavanju klupske djelatnosti i kvalitete njegovih programa.

Nastavljajući tradiciju povezivanja škole s organizacijama udruženog rada, članovi Kluba su u ožujku 1981., uspostavili suradnju s animatorima kulture koprivničke industrije Podravka. Prilikom svojeg posjeta Koprivnici razgledali su njene proizvodne pogone i izložbeni prostor i dogovorili da krajem mjeseca Podravkina likovna i literarna sekcija za učenike i građanstvo u Klubu prirede izložbu slika i književnu večer, ostvarujući neku vrstu Dana Podravke u Varaždinu. ${ }^{111}$ Tijekom sljedećeg mjeseca u organizaciji Kluba u koprivničkoj Podravki su za radnike ovog kolektiva nastupili literati, recitatori, pjevači i ritmička sekcija Centra, izvodeći zanimljivu zabavno-glazbenu priredbu, čime su Varaždinci uzvratili posjet članovima Podravkinih sekcija. ${ }^{112}$ Dana 13. lipnja 1981. Klub je znatno pridonio uključivanju Centra u sigurnosnu akciju šire zajednice Ništa nas ne smije iznenaditi 81, održane u okviru uspješne vježbe sklanjanja učenika i organiziranja logorskog života pod šatorima u slučaju zračnog napada. Članovi Kluba su, pod pretpostavkom oštećenja školske zgrade, u dvorištu obližnjeg dječjeg vrtića podigli šatore za smještaj mladeži i improvizirane kuhinje, pripremivši

\footnotetext{
108 Iz spomenutog popisa saznajemo kako je, osim radio i TV-aparata, Klub između ostalog raspolagao s: nekoliko gramofona, s više zvučnika i mikrofona, stolom za razglas, pojačalima, magnetofonom, kazetofonom, regulatorom svjetla i automatskim dijaprojektorom, što je uglavnom bilo nabavljeno uz pomoć vlastitih sredstava ili osigurano poklonima donatora (op. a.).

109 Primopredajni zapisnik s redovnog sastanka Uprave omladinskog kluba V3 od 26. X. 1982.

110 Razgovor profesora Milkovića s autorom u lipnju 2018. godine.

111 "Mladi Podravka", Varaždinske vijesti, br. 9. od 5. III. 1981., str. 12.

112 "Članovi Kluba V3 Podravki", Varaždinske vijesti, br. 18 od 7. V. 1981., str. 16.
} 
100-ak obroka. ${ }^{113}$ Godinu 1981./82. Klub je započeo izložbom Ivančica 81 , koja je bila postavljena 22.- 24. rujna. To je bila izložba fotografija sa sedmodnevnog logorovanja članstva Kluba na Ivančici, organiziranog po završetku prethodne godine. ${ }^{114} \mathrm{Uz}$ foto-materijal, na izložbi je prikazan i dio logorske opreme, što ju je učinilo raznolikom i posjetiteljima zanimljivijom. ${ }^{115}$

No u ovim su se godinama u radu Kluba počeli nazirati i prvi znakovi krize. Povlačenjem prof. Bračka voditelji Kluba su se izmjenjivali u kratkim vremenskim razmacima. Premda je svatko od njih svakodnevnim zalaganjem značajno pridonosio njegovom radu, česte izmjene voditelja ukazuju na to da im je, uz oduševljenost radom s mladima, ta dužnost ipak predstavljala opterećenje $s$ kojim se nisu mogli trajnije nositi. Tim više jer je briga za red i sigurnost tijekom subotnjih plesova čiji termini su se produživali, postajala sve zahtjevnija. Kako je nakon plesa klupski prostor redovito valjalo dovoditi u stanje u kojem bi ga tijekom tjedna mogli koristiti, to je znatno povećavalo odgovornost i opterećenje i za dežurne učenike i za voditelja. Kako je prof. Milković u Centru zadržao samo pola satnice, Savjet Centra je na prijedlog Uprave Kluba na dužnost voditelja 8. listopada 1982., imenovao prof. Josipa Novaka koji je i do tad podupirao njegov rad. ${ }^{116}$ Primopredaja dužnosti obavljena je na redovnom sastanku Uprave kluba 26. listopada 1982. godine. ${ }^{117}$

Velik dio prihoda umanjivan opadanjem posjećenosti disco-većerima i rastućom inflacijom u uvjetima ekonomske stabilizacije, usmjeren je na trošak disc-jockeya i izlete članova Uprave Kluba. Pritom valja naglasiti da su troškovi spomenutih izleta uvijek svođeni na minimum, smještajem i prehranom u logorskim uvjetima, a trošak putovanja drastično je umanjivan korištenjem povlastica za grupna putovanja mladeži. ${ }^{118}$ Vodstvo Kluba se za potporu počelo obraćati Omladinskoj organizaciji. Prijepora je bilo i u načinu odabira novih članova Uprave Kluba. Na temelju tadašnjeg Statuta Kluba njenim se članom moglo postati na prijedlog vlastitog razreda ili barem četvoro članova Uprave Kluba. ${ }^{119}$ Prema ocjeni omladinskog vodstva, nove se članove najčešće primalo na prijedlog dosa-

\footnotetext{
113 "U SŠC "Gabriel Santo" uspješna evakuacija”, Varaždinske vijesti, br. 24 od 18. VI. 1981., str. 9.

114 Logorovanjem je bilo obuhvaćeno 30 -ak članova Uprave kluba gdje je, uz radne zadatke i vježbe, bilo prilike za odmor i zabavu (op. a.).

115 "Završena izložba Ivančica 81", Varaždinske vijesti, br. 39 od 1. X. 1981., str. 10.

116 Odluka Savjeta Srednjoškolskog centra "Gabrijel Santo" Varaždin, br. 1323/82 od 8. XI. 1982.

117 Primopredajni zapisnik sa sastanka Uprave Omladinskog kluba V3 od 29. X. 1982.

118 Potvrda za korištenje povlastica $40 \%$ od redovne cijene prijevoza za grupna putovanja učenika, polaznika, studenata, omladine i djece vlakom-brodom, putovanje na relaciji Varaždin - Rijeka od 10. I. 1984. (op. a.).

119 Statut Omladinskog kluba V3 iz 1979., čl. $18-22$.
} 
dašnjih, što je s vremenom dovelo do izvjesnog zatvaranja jer je djelovanje Kluba palo pod kontrolu manje skupine koja si je ovaj naporan dodatni rad, kako je to protumačeno u Omladinskoj organizaciji, nastojala honorirati. ${ }^{120}$ Između omladinskog vodstva i vodstva Kluba stvorena je napetost, posebno kad je Omladinska organizacija odbila financijski pomoći Klubu. ${ }^{121}$ Početkom 1983., sazvan je sastanak s ciljem da se stišaju napetosti, a prigovori na rad Kluba pokažu kao neopravdani. ${ }^{122}$ Da je situacija bila ozbiljna potvrđuje i činjenica da je o stanju u Klubu raspravljalo i Predsjedništvo OK SK. ${ }^{123} \mathrm{~S}$ obzirom na loš materijalni položaj Kluba, Predsjedništvo mu je odobrilo pomoć ali je zaključeno da se na jednoj od narednih sjednica opširnije raspravi o stanju u Centru.

Usprkos teškoćama, aktivnosti Kluba uspješno su se nastavljale. Uvečer 21. veljače 1983., posjetiteljima je o poeziji govorio i čitao svoje pjesme književnik Ernest Fišer. ${ }^{124}$ Dva mjeseca kasnije ponovno je priređen vrlo uspješan koncert čuvenog Drage Mlinarca. ${ }^{125}$ Odaziv je i ovoga puta bio toliki da je dvorana bila premala za sve zainteresirane. Na koncertu je prevladavalo izuzetno ozračje kojem je pridonio i sam Mlinarec neposrednim pristupom slušateljstvu. Tijekom koncerta mnogi su ga dva puna sata podržavali, pjevajući zajedno s njim. Par dana kasnije, točnije 19. travnja 1983., u Klubu su postavljene dvije izložbe, ${ }^{126}$ a među zapaženijim izvođačima koncert je održao popularni country sastav Plava trava zaborava. ${ }^{127}$ Krajem svibnja 1983. Klub je održao godišnju skupštinu na kojoj je donesen novi statut. Izabrani su novi članovi predsjedništva, dok je dio bivših ostao u počasnom statusu. Na skupštini je donesen bogat plan rada koji je već tradicionalno obuhvaćao organizaciju discovečeri, izložbe, predavanja, prigodne akademije, gostovanja istaknutih javnih osoba i izlete. ${ }^{128}$ Predvođena novim vodstvom, mladež je preuredila klupski prostor. ${ }^{129}$ Po-

\footnotetext{
120 Razgovor i pismo g. Tihomira Englera, tadašnjeg predsjednika Saveza socijalističke omladine na SC "Gabriel Santo" autoru 15. II. 2018.

${ }^{121}$ Sastanku su prisustvovali članovi Uprave Kluba i i Predsjedništva SSO Centra, ravnateljica, sekretar SK škole i načelnik SUP-a (op. a.).

122 Razgovor i pismo g. Tihomira Englera, tadašnjeg predsjednika Saveza socijalističke omladine na SC "Gabriel Santo" autoru 15. II. 2018.

123 Predsjedništvo OK SK Varaždin Udruživanje sredstava za održavanje objekata kulture - neophodna potreba, Varaždinske vijesti, br. 5 od 3. II. 1983., str. 1.

124 "Klub V3", Varaždinske vijesti, br. 7 od 17. II. 1983., str. 7.

125 "Koncert D. Mlinarca", Varaždinske vijesti, br. 15 od 14. IV. 1983., str. 16.

126 Izlagali su Marijan Klepač koji je izlagao na svim izložbama Likovnog udruženja Varaždin i po prvi puta, Davor Radmilović (op. a.).

127 Pismo Igora Čolakovića autoru od 21. XI. 2019. godine.

128 "Peti tri u novom ruhu", Varaždinske vijesti, br. 23 od 2. VI. 1983., str. 16.

${ }^{129}$ Skidana je stara boja i napukla žbuka, krpani su zidovi, nanošena svježa boja nakon čega je uslijedilo
} 
četkom nove godine u organizaciji enigmatskog društva Vazak u Klubu je postavljena zanimljiva izložba rebusa zagonetaka te knjiga i edicija na temu enigme. ${ }^{130}$ Tijekom njenog trodnevnog trajanja razgledali su je gotovo svi učenici Centra, ali i mnogi drugi. ${ }^{131}$ Uz svečanu akademiju priređenu na sam Dan kluba, 17. - 22. listopada 1983., u školi su povodom toga održavani koncerti, sportske priredbe i recitali. ${ }^{132}$ Kako je zgrada varaždinskog kazališta u tom periodu bila u rekonstrukciji, njegov je ansambl predstave izvodio u školama i radnim organizacijama. ${ }^{133}$ Tako je u prostoru Kluba održana premjera Čopićeve monodrame Pepo Bandić, te je bila izvedena predstava Kako nastaje kazališna predstava Karela Čapeka. Početkom šk. g. 1984./85. učenici odgojno-obrazovnih usmjerenja Centra su u Klubu priredili didaktičku izložbu svojih radova. Na izložbi su bili prezentirani radovi iz programa nastave likovne kulture za smjer razredne nastave i predškolskog odgoja. ${ }^{134}$

Pod vodstvom nove voditeljice, mlade profesorice Milade Erhatić Klub je pronalazio izlaz iz teškoća. Među varaždinskom mladeži dobro poznate subotnje disco-večeri i nadalje su bile jedini izvor prihoda i jedina takva zabava za mlade Varaždina. U odnosu na prethodnu godinu bile su dobro posjećene, okupljajući 200-300 mladih. Organizirano je predavanje o republičkoj alpinističkoj ekspediciji Obojene planine, zatim izložba nakita učenika II. osnovne škole, povodom Dana JNA bila je postavljena izložba mina iznenađenja, a priređena je i tradicionalna novogodišnja tombola. ${ }^{135}$ Ususret 350-godišnjici varaždinske Gimnazije krajem prosinca 1984. priređena je izložba računala. Nakon otvorenja uslijedila je demonstracija rada pojedinih računala. ${ }^{136}$ Organizatori akcije i vlasnici izloženih računala bili su učenici informatičkog usmjerenja Centra. Izložba je poslužila kao svojevrstan uvod u zimsku školu programiranja koju je Centar planirao provesti tijekom zimskih praznika ${ }^{137}$ pa je 20.- 22. ožujka 1985. za učenike osnovnih škola održavana demonstracija računala Orao i programa informatičkog usmjerenja.

temeljito čišćenje (op. a.).

130 Svoje radove predstavili su Robert Odniković, Predrag Ostrički, Miljenko Košutar i Davor Brlek, dok je Darko Galić izložio fotografije s natjecanja zagonetača u Splitu i Zvorniku (op. a.).

131 "Izložba zagonetaka", Varaždinske vijesti, br. 41 od 6. X. 1983., str. 12.

132 "Tjedan Kluba V3", Varaždinske vijesti, br. 45 od 3. XI. 1983., str. 7.

133 "Kazališne predstave izvan kazališta", Varaždinske vijesti, br. 2 od 19. I. 1984., str. 7.

134 "Likovna didaktička izložba", Varaždinske vijesti, br. 38 od 27. IX. 1984., str. 7.

135 Novo buđenje Kluba V3, Varaždinske vijesti, br. 51-52 od 27. XII. 1984., str. 9.

136 Izložbu je službeno otvorio mr. Vladimir Špiranec u prisutnosti članova Savjeta za informatiku Skupštine općine Varaždin. Posjetiocima je omogućen rad na Galebu, Orlu, Apple II, Spectrumu, ZX 81, Commodoru 64, Galaksiji, Texas Instrumentsu i KAGu (op. a.).

137 "Izložba mikro-računala", Varaždinske vijesti, br. 1 od 10. I. 1985., str. 6. 


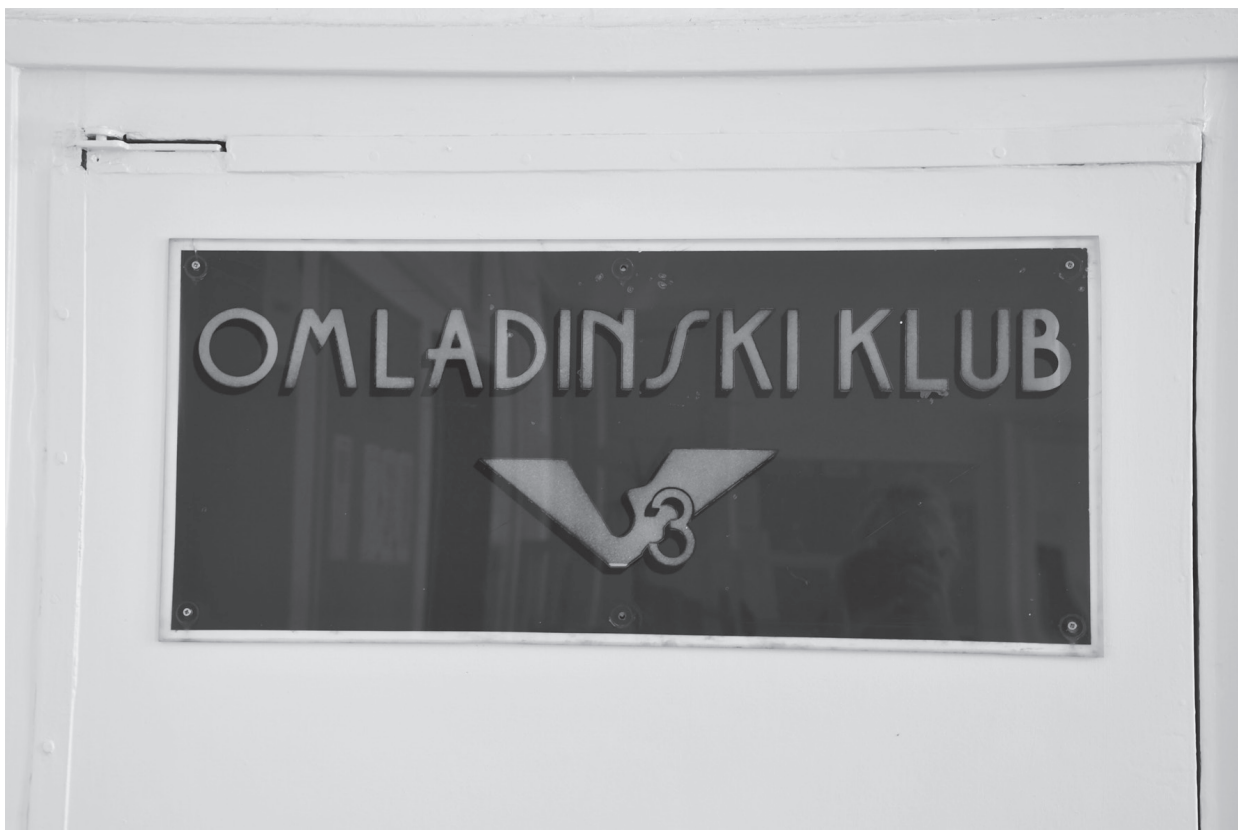

Slika 3. Ploča s nazivom Kluba

U ovom su razdoblju u okviru klupskih aktivnosti obnovljeni pokušaji oživljavanja filmskih projekcija. ${ }^{138}$ Ponedjeljkom su održavane filmske tribine u sklopu kojih se svakog drugog tjedna prikazivao film nabavljen iz Filmoteke 16. Petkom je profunkcionirala glazbena tribina. Pored slušanja glazbe po sistemu jer ste vi to tražili, povremeno su bili održavani i koncerti. U okviru klupske glazbene tribine u petak 22. ožujka 1985., održan je koncert Dixiland band Glazbene škole Varaždin. ${ }^{139}$ Obnovljena je i plesna škola koju su, uz naplatu, mogli pohađati i ostali, dok je za učenike Centra bila besplatna. ${ }^{140}$

Potkraj 1984./85. u Klubu je po prvi puta upriličena izložba stripa, ujedno i prva takva izložba u Varaždinu. Autor izloženog stripa bio je učenik II. razreda Vjeran Miljenović, koji je izložio kompletan strip u 8 tzv. listova napravljenih tušem, a ujedno je bio i autor scenarija. Izložba je pobudila zanimanje brojnih ljubitelja stripa pa se počelo razmišljati o mogućnosti da sljedeće godine izlažu i ostali

\footnotetext{
138 Pismo autoru od tadašnje voditeljice Kluba, profesorice Milade Erhatič.

139 "Klub "V3" kompjutori za osnovce", Varaždinske vijesti, br. 11 od 21. III. 1985., str. 16.

140 "Tribine - filmovi", Varaždinske vijesti, br. 8 od 28. II. 1985., str. 9.
} 
autori stripova kao svojevrsni ciklus stripa. ${ }^{141} \mathrm{U}$ suradnji s Čakovečkom školom stripa i crtanog filma pokrenuta je i škola stripa. ${ }^{142}$ Uoči novogodišnjih praznika u Klubu su se godinama održavali prigodni programi podjele darova djeci djelatnika škole, a klubaši su veliku pozornost tradicionalno posvećivali novogodišnjim tombolama. Pritom su donacije obično tražili u lokalnim tvrtkama. U ponedjeljak 30. prosinca 1985., Klub je priredio Novogodišnju tombolu s 200-ak nagrada, ${ }^{143}$ a u skladu s trendom, glavna nagrada bilo je računalo Orao, druga nagrada 20000 din., a treća, grafike Miroslava Šuteja. ${ }^{144}$

No za Klub su ubrzo uslijedili novi problemi. U međuvremenu su disco-većeri počeli priređivati i učenici varaždinskog Metalskog elektro-centra, što je dovelo do suparništva između poklonika diskača u MEC-u i Kluba, pa i međusobnog uništavanja plakata. Došlo je do spora pri pokušaju usklađivanja termina održavanja disco-većeri, što se nije uspjelo razriješiti i štetilo je objema stranama. $\mathrm{S}$ vremenom je ipak došlo do smirivanja napetosti i do suradnje, priređivanjem breakedance natjecanja i kroz zajednička sudjelovanja na Danima maturanata. Smanjivanju prihoda Kluba pridonijela je i organizacija disco-večeri u prostoru Fakulteta organizacije i informatike, iako se, za razliku od MEC-a, u FOI-u okupljala nešto starija populacija. U Klubu su ulaznice bile skuplje nego u MEC-u, a simbolično je naplaćivana i garderoba. ${ }^{145}$ No osim plesnih večeri, Klub je godinama uspješno organizirao koncerte i nastupe rock-sastava, pa su, uz legendarnog Dragu Mlinarca u ovom periodu u Klubu nastupili Telefon i Neki to vole vruće. Priređivan je i niz drugih kulturno-zabavnih i obrazovnih sadržaja poput posjeta značajnih osoba, predavanja i tribina na temu kulture, znanosti, tehnike, informatike i drugih područja zanimljivih srednjoškolcima, čime se novooformljena središta zabave nisu mogla pohvaliti. Nastalu krizu u djelovanju Kluba nastojalo se prevladati sazivanjem sastanka članova Predsjedništva Kluba, predstavnika OK SSO ${ }^{146}$ i direktorice Cemtra. U SSO vladalo je uvjerenje da je unutar škole prisutna podvojenost mladeži te da ih je potrebno objediniti. No, vodstvo Centra bilo je uvjereno kako se radi samo o malom zastoju u radu, a rješenje se tražilo

\footnotetext{
141 "Strip V. Miljenovića", Varaždinske vijesti, br. 25 od 27. VI. 1985., str. 16.

142 Pismo autoru od tadašnje voditeljice Kluba, profesorice Milade Erhatič.

143 "Novogodišnja tombola u "V3", Varaždinske vijesti, br. 51 - 52 od 26. XII. 1985., str. 10.

144 Od ostalih ponuđenih zgoditaka bilo je moguće osvojiti još: nekoliko večera za dvije osobe u pojedinim varaždinskim ugostiteljskim objektima, besplatno polaganje vozačkih ispita za bicikle s pomoćnim motorom i telefonski razgovor sa zapadnom Europom. Zatim su bile ponuđene klizaljke, muške i ženske, vrijedne knjige i drugo (op. a.).

145 "Život u ritmu muzike za ples", Varaždinske vijesti, br. 20 od 23. V. 1985., str. 11.

146 Općinska konferencija Saveza Socijalističke Omladine.
} 
u izradi novog statuta Kluba. Pod njegovim okriljem nastojalo se objediniti sve slobodne aktivnosti u Centru. Predsjednici pojedinih aktivnosti bili bi ujedno i članovi Predsjedništva Kluba. Tako se željelo postići jedinstvo mladeži Centra, a svi učenici postali bi članovi Kluba. Kako bi klubaši mogli slobodno organizirati predavanja kojima bi zainteresirani učenici nesmetano prisustvovali, u školskom rasporedu planirano je oslobađanje jednog sedmog sata tjedno, čime bi se olakšalo uključivanje polaznika obiju smjena. Termin disco-večeri premješten je sa subote na nedjelju, čime se nastojalo utjecati na povećanje prihoda i osigurati financijsku samostalnost Kluba. ${ }^{147}$

Aktivnosti Kluba nadalje su se nastavile uspješno organizirati. Ususret 350-godišnjici Gimnazije na prigodnoj svečanosti upriličenoj u prostoru Kluba, djelatnici Centra primili su Srebrnu plaketu JNA, visoko vojno priznanje Komande Zagrebačke armijske oblasti. ${ }^{148}$ "Priznanje za izuzetno kvalitetne rezultate u obrazovanju, idejno-političkom usmjeravanju omladine, zbog razvijanja uspješne suradnje $s$ jedinicama i ustanovama JNA, te u povodu predstojećeg jubileja-350 godišnjice", predao je general-potpukovnik Kemal Buzaljko, predstavnik Komande Zagrebačke armijske oblasti, a u ime. kolektiva, primila ga je direktorica, prof. Emina Gomaz. U organizaciji Kluba 18.- 21. veljače 1986. priređena je izložba stripa učenika Centra, a Klub je planirao prirediti Čagu za starije s glazbom 60-ih. ${ }^{149}$ To je ostvareno u subotu, 26. travnja 1986., kad je priređena posebna večer rock-glazbe za starije generacije, pa su u Klub mogli ući samo stariji od 27 godina. U periodu 22.- 25. travnja, učenici Tekstilne škole postavili su zanimljivu izložbu, izlažući kreacije i modele koje su izradili tijekom praktičnog dijela nastave. ${ }^{150}$ Kako su se u organizaciji Kluba priređivala natjecanja i turniri u raznim sportskim disciplinama, obnovljeni su i turniri u šahu. ${ }^{151}$ Dana 24. svibnja 1986., u Klubu je u okviru 25. Susreta, smotre stvaralaštva mladih općine Varaždin, održan Turnir u šahu. ${ }^{152} \mathrm{U}$ sklopu ovih Susreta u Klubu je promovirana i prva zbirka pjesama mladog varaždinskog pjesnika Ivice Gecija Raščerečeni vjekovi. Uz njega, Varaždincima se svojim likovnim ostvarenjima predstavio i mladi slikar, amater Mladen Jakopan Čača. ${ }^{153}$

\footnotetext{
147 "Što se događa u Klubu V3?", Varaždinske vijesti, br. 13 od 3. IV. 1986., str. 7.

148 "Dodijeljena visoka vojna priznanja SŠC "Gabriel Santo", Varaždinske vijesti, br. 1 od 9. I. 1986., str. 1.

149 "Klub V3, Izložba stripa i čaga", Varaždinske vijesti, br. 7 od 20. II. 1986., str. 10.

150 "Omladinski klub V3 glazba 60-tih", Varaždinske vijesti, br. 16 - 17 od 24. IV. 1986., str. 6.

151 Pismo Ivice Kruhoberca upućeno autoru 28. X. 2019.

152 "Uz srebrni jubilej 'susreta', Nov koncepcija - uspjeh ili fijasko", Varaždinske vijesti, br. 23 od 12.VI. 1986., str. 11.

153 "Završeni ovogodišnji 25. susreti mladih općine Varaždin, Uspješna organizacija i kvalitetan program",
} 
Kako je i na našim prostorima porasla svijest o opasnosti od AIDS-a, u školama i poduzećima počelo se organizirati predavanja na tu temu ${ }^{154}$ pa je i Klub organizirao slična predavanja. ${ }^{155}$ Krajem ožujka 1987., Klub je ugostio poznatog književnika i publicista Oskara Daviča. Čuveni pisac slušateljstvu je govorio o svojem predratnom revolucionarnom radu, prijateljima, suborcima i poratnim prilikama koje su imale utjecaja na jugoslavensku književnost. U učeničkim pitanjima nije bio zaobiđen ni njegov roman Pesma, koji je ocijenjen kao prekretnica u tretiranju ratnog romana. ${ }^{156}$ Prostor Kluba mjesecima je bio na raspolaganju grupi Glavno da se gura koju je žiri Kluba odabrao da predstavlja Varaždin na Gitarijadi Zadar 87. ${ }^{157}$ Nakon opsežnih priprema, band je 23. travnja 1987., prvo nastupio u Klubu, a 25. travnja, nastupio je na spomenutoj Gitarijadi. ${ }^{158}$ Profilirajući se kao škola u kojoj se unapređuje matematičko-informatičko obrazovanje, Centar je poduzimao akcije kojima je informatiku nastojao predstaviti široj javnosti. $U$ organizaciji SSO Varaždin, Kluba i Informatičke grupe Centra, 2. - 4. studenoga 1987., priređena je izložba. Informatički dani, na kojoj su učenici posjetiocima demonstrirali vlastito umijeće na računalima. ${ }^{159}$

\section{PAD AKTIVNOSTI}

Kako bi se razriješilo goruće probleme Kluba od postavljanja voditelja do problema financiranja, osipanja kadra i članstva te dotrajalosti instalacija, odlučeno je da se provede reorganizacija. U tu svrhu uspostavljena je tješnja suradnja između Omladinske organizacije Centra i vodstva Kluba. Njegovo vođenje bilo je povjereno tzv. Koordinacijskoj grupi, a sve aktivnosti omladine nastojalo se prenijeti u Klub koji je uključen u sustav Omladinske organizacije škole. ${ }^{160}$ Odlučnost odgovornih u školi i novog omladinskog vodstva doveli su do zanimljivih inicijativa. Među učenicima su provedene ankete, svaki je razred predlagao buduće aktivnosti Kluba. Predložena su predavanja s tematikom koja intrigira mladež.

\footnotetext{
Varaždinske vijesti, br. 50 od 18. XII. 1986., str. 3.

154 "Da li AIDS (SIDA) kuca na vrata Varaždina? Puna pažnja edukaciji i preventivi", Varaždinske vijesti, br. 19 od 14. V. 1987., str. 8.

155 Kao predavač im je pomagala Dr. Nada Špiranec, rukovoditeljica Odjela za infektivne bolesti Opće bolnice Varaždin (op. a.).

156 "U SŠC 'Gabriel Santo', Sat s Oskarom Davičom", Varaždinske vijesti, br. 13 od 2. IV. 1987., str. 1.

157 "Glavno da se gura, zaista", Varaždinske vijesti, br. 7 od 19. II. 1987., str. 7.

158 "Dogurali možda i do finala", Varaždinske vijesti, br. 20 od 21. V. 1987., str. 9.

159 "SC 'Gabriel Santo', Raznovrsno i zanimljivo", Varaždinske vijesti, br. 43 od 29. X. 1987., str. 6.

160 "Omladinski klub V3, Ipak se kreće", Varaždinske vijesti, br. 48 od 8. XII. 1987., str. 14.
} 
Razmišljalo se o organiziranju zabavnog kviza, plesne škole, izložbi, natjecanja u pjevanju i plesu, književnih večeri, glazbene slušaone, informatičkog tjedna. Ponovno su planirani sadržaji koji bi učenicima putnicima omogućili boravak u prostoru Kluba. No priređivanje disco-večeri moralo se odgoditi jer se pokazalo da oprema i instalacije više nisu funkcionalni, a valjalo je organizirati dežurstva do sitnih sati i održavanje reda među posjetiocima, za što očito više nije bilo motiva. ${ }^{161}$ To je otvorilo i pitanje financiranja pa je veza s Omladinskom organizacijom neizbježno učvršćena. Premda je od početka 1988./89., Klub neko vrijeme djelovao bez voditelja, aktivnosti su s vremenom ponovno profunkcionirale. Najdalje se otišlo s organizacijom Video kluba 350. U Klubu su petkom s početkom u 19 sati, uz simboličnu ulazninu, bili prikazivani filmovi s video-kazeta. ${ }^{162}$

Povodom Dana žena, Klub je s omladinom poduzeća Mundus „Florijan Bobić" i dizajnerima tekstilne škole, 1.- 8. ožujka 1988., organizirao prodajnu izložbu Harmonija mode boja i oblika. Bila je to prigodna prodajna izložba na kojoj se moglo razgledati i kupovati tijekom čitavog tjedna, ${ }^{163}$ a na 8 . ožujka priređena je modna revija. ${ }^{164}$ Kazališna grupa Domino, nastala ponovnim okupljanjem dijela omladinskog dramskog studija $A C 77$, u Klubu je krajem mjeseca premijerno izvela Cvjetnu dolinu prema adaptaciji teksta Milana Begovića, a sponzor i suorganizator bio je SSO Varaždin. ${ }^{165}$ Sredinom svibnja 1988., zanimljivo predavanje održao je poznati novinar Joža Vlahović, a u dvosatnom razgovoru prisutni su saznali brojne zanimljivosti, od novinarstva do društveno-političkih aktualnosti. ${ }^{166}$

No u nedostatku entuzijasta, bez odgovornog voditelja i stalnog dodatnog prihoda, aktivnosti Kluba gubile su kontinuitet. Njegov se prostor sve češće koristio za odvijanje dijela redovite nastave, posebno tijekom popravaka u sportskoj dvorani. Na stanje u Klubu utjecale su i korjenite promjene koje su se upravo događale u državi i društvu. Za ubrzani proces odumiranja krivicu je, zahvaljujući neaktivnosti, dijelom snosila sama omladina. Sazvan je hitan sastanak direktora i Predsjedništva Kluba. Novoimenovani direktor, ing. Velimir Klinec naglasio je kako se "treba okrenuti budućnosti i reafirmaciji još uvijek jedinog prostora za slobodno odvijanje aktivnosti omladine centra, pa i šire". ${ }^{167}$ Po tko zna koji put,

\footnotetext{
161 "Klub V3, Novo ruho za starohg ljepotana", Varaždinske vijesti, br. 45 od 12. XI. 1987., str. 7.

162 "Omladinski klub V3, Ipak se kreće", Varaždinske vijesti, br. 48 od 8. XII. 1987., str. 14.

163 Među izlošcima našlo se nakita, dekorativne keramike, detalja od kože i drva (op. a.).

164 "Povodom 8. marta, Izložba i Klubu V3", Varaždinske vijesti, br. 8 od 3. III. 1988., str. 6.

165 "Kultura mladih, "Cvjetna cesta" - premjera u "V3", Varaždinske vijesti, br. 12 od 31. III. 1988., str. 7.

166 "Susret s Jožom Vlahovićem", Varaždinske vijesti, br. 18 od 12. V 1988., str. 17.

167 "Omladinski klub V3 - još jednom na početku kraja, I ukidanje je sudbina”, Varaždinske vijesti, br. 42 od 26. X. 1989., str. 11.
} 
kreirani su planovi ozdravljenja i oblikovana radna jezgra od nekolicine pojedinaca spremnih da svojim radom vrate Klubu stari sjaj. No, sve je ovisilo o zalaganju mladih, dok je škola bila spremna moralno, materijalno i financijski podržati takvu aktivnost.

U međuvremenu je upravo iz omladinske organizacije uslijedila inicijativa o povratku naziva Gimnazija. Na sjednici Predsjedništva OK SSOH Varaždin 27. veljače 1990., zaključeno je da predstavnici omladine prijedlog upute Skupštini općine. ${ }^{168}$ Nastavničko vijeće Centra 25. travnja 1990., donijelo je odluku o promjeni imena škole. Nakon brojnih poticaja s raznih strana, Predsjedništvo Skupštine općine, na svojoj je sjednici od 11. srpnja, također podržalo ovu inicijativu, a dan kasnije podržao ju je i referendum zaposlenika škole. ${ }^{169}$ Početkom 1990./91. u dotad polivalentnom obrazovnom centru počelo je uvođenje gimnazijskih nastavnih programa, prema kojima je od ukupno 43 razreda, radilo njih $30 .{ }^{170}$ Svečanost povodom promjene imena škole započela je u petak 16. studenoga 1990. navečer, priredbom u varaždinskoj Koncertnoj dvorani. ${ }^{171}$ Središnji događaj 17. studenoga, bilo je otkrivanje nove ploče na zgradi škole. Bosiljka Paska, umirovljena dugogodišnja ugledna profesorica svečano je otkrila ploču s imenom Gimnazija Varaždin. ${ }^{172}$ Nakon toga škola je otvorena za razgledavanje uvodnim otvorenjem izložbe radova 19 umjetnika, bivših učenika koji su kao sjećanje na školske dane, školi poklonili po jedno svoje djelo.

U postojećim okolnostima u radu Kluba ponovo je uslijedila stagnacija, što se očitovalo u priređivanju svega par aktivnosti godišnje. Prema riječima Krste Kožnjaka, predsjednika Kluba u rad se nastojalo uključiti što više učenika, a za početak, Klub se priključio proslavi povodom vraćanja starog imena škole. Tradicionalni izbor za Miss i Mistera organiziran je 16. studenoga 1990., uz modnu reviju učenika Tekstilnog školskog centra, a dan kasnije Klub se uključio u program za učenike. U klupske aktivnosti planiralo se uključiti sve slobodne aktivnosti u školi i otvoriti ga učenicima u vrijeme kada nemaju nastavu te animirati njihovo slobodno vrijeme. Namjeravalo se organizirati sportske turnire, a početkom iduće godine gitarijadu i koncerte domaćih bendova. U sklopu Kluba počeo je izlaziti i

\footnotetext{
168 "Inicijative, 'G. Santo' ponovo "Gimnazija" ", Varaždinske vijesti, br. 9 od 8. III. 1990., str. 1.

169 "G. Santo na putu u 'Gimnaziju' ", Varaždinske vijesti, br. 32 od 16. VIII. 1990., str. 9.

170 "Srednjoškolski centar Gabriel Santo - početak školske godine u novoj formi, Dvije trećine općeg obrazovanja", Varaždinske vijesti, br. 38 od 27. IX. 1990., str. 3.

171 "Srednjoškolski centar Gabriel Santo pred promjenom imena, Povratak Gimnazije", Varaždinske vijesti, br. 44 od 8. XI. 1990., str. 3.

172 "Od sada pa zauvijek - Gimnazija", Varaždinske vijesti, br. 46 od 22. XI. 1990., str. 2.
} 
školski list Spleen. ${ }^{173}$ Nakon niza godina izbivanja, Društvo za uzgoj i zaštitu sitnih životinja odlučilo je 2. i 3. veljače 1991., prirediti svoju tradicionalnu izložbu u gimnazijskom Klubu. ${ }^{174} \mathrm{~A} 28$. veljače Klub je, nakon dužeg prekida, ponovo ugostio rockere. Ova Gitarijada predstavljala je prekid duže lokalne rockerske šutnje ${ }^{175}$ i pokazala da postoji zanimanje za ovaj tip glazbe. Premda je njena kvaliteta bila neusporediva s onima iz boljih vremena domaćeg rocka, u gimnazijskom Klubu se nakon dužeg vremena uživo sviralo. ${ }^{176}$

Premda su se na varaždinskom području izravne borbe vodile relativno kratko, početak 1991./92. bio je otežan zbog borbenih aktivnosti na širem prostoru. Nastavni program se tijekom godine, bez obzira na izgubljene dane, nastojao u potpunosti ostvariti. Zbog učestalih uzbuna nastava se prekidala, a učenici su se s profesorima, tijekom zračne opasnosti, sklanjali u školski podrum, točnije u prostore Kluba. Uključivali su se u humanitarne akcije, od darivanja krvi, prikupljanja pomoći, do brige o ranjenima u bolnici. ${ }^{177}$ Glazbena grupa Arena, sastavljena od učenika Gimnazije i Glazbene škole, krajem listopada 1991., u Klubu je priredila dobrotvorni koncert, ${ }^{178}$ a ulaznina je namijenjena njihovim vršnjacima na bojištu. ${ }^{179}$

U ovakvim okolnostima aktivnosti Kluba su prestale, a njegov prostor bio je uglavnom neiskorišten. U okviru korjenitih promjena društveno-ekonomskih uvjeta i nastupajuće privatizacije koja je na prijelazu u 90-te godine XX. stoljeća zahvatila Republiku Hrvatsku, vodstvo škole je odlučilo prostor Kluba iznajmiti. ${ }^{180}$ Namjera je bila da najmoprimatelj za potrebe škole organizira prehranu učenika prodajom prehrambenih artikala i napitaka, uz uvjet da prema potrebi, Gimnazija prostor može koristiti za kulturno-zabavne i izvannastavne aktivnosti. Prostor Kluba planiralo se ponovo pretvoriti u Klub Gimnazije sa željom da postane intelektualnim središtem u kojem bi se okupljali Gimnazijalci, ali i drugi, od bivših

173 "Budi li se iz mrtvila gimnazijski Klub "Peti tri", Dobra volja i planovi", Varaždinske vijesti, br. 47 od 29. XI. 1990., str. 14.

174 Više desetaka rasa golubova, kunići, kanarinci, papige i ukrasna perad posjetiocima su predstavljeni u subotu, 2. veljače, od 8 do $20 \mathrm{~h}$, a u nedjelju, 3. veljače od 8 do $16 \mathrm{~h}$ (op. a.).

175 Nastupile su grupe: The Bugs iz Čakovca, Big Balls iz Ludbrega te Ventilator 202, The Thrills i Peregrini iz Varaždina (op. a.).

176 "Gitarijada Peregrini, Preko lokalne rockerske šutnje", Varaždinske vijesti, br. 10 od 14. III. 1991., str. 16.

177 "Gimnazija Varaždin, Živjeti normalno", Varaždinske vijesti, br. 43 od 31. X. 1991., str. 11.

178 Organizaciju koncerta pomogao je razredni odjel IV inf. c. Sakupljeni novac od 2.295 din.dostavljen je Organizaciji Crvenog križa koja ga je trebala proslijediti na ratište (op. a.).

179 "Grupa "Arena" za vršnjale na frontu", Varaždinske vijesti, br. 44 od 7. XI. 1991., str. 20.

180 Varaždinske vijesti, br. 28 od 18. VII. 1991., str. 14. 
učenika i profesora do varaždinskih kulturnih djelatnika. Ponovno su najavljivani planovi o priređivanju književnih večeri, promocija, koncerata ozbiljne i zabavne glazbe, plesnih tečajeva, filmskih projekcija, tribina i razgovora. U Klubu bi boravili učenici putnici, uz osiguravanje brze prehrane. ${ }^{181}$ Krajem 1991. prostor Kluba bio je iznajmljen firmi Thalia d. o. o. čiji su ga vlasnici uredili kao klub Palestra. ${ }^{182}$ Uvedena je cjelodnevna ugostiteljska ponuda s prehranom za učenike od 7 do 19 sati. Petkom su planirane disco-večeri u trajanju od 20 sati navečer do 03 ujutro, dok je za sve druge oblike aktivnosti poput plesne škole, koncerata pa do organiziranog dočeka Nove Godine i sl., postojala mogućnost dogovora. ${ }^{183}$ Premda ne postoji nikakva službena odluka o prekidu ili prestanku njegovog rada, društveno-političke promjene i ratne okolnosti u konačnici su dovele do zamiranja i konačnog prekida djelovanja Omladinskog kluba V3 varaždinske Gimnazije.

Spomenuta inicijativa se nažalost nije održala pa je kontinuitet omladinske klupske aktivnosti bio prekinut. Tek nakon 10-ak godina, početkom 2000-tih, na poticaj tadašnje ravnateljice prof. Rajke Ptiček, prof. Dražena Dragovića i nekolicine mladih entuzijasta predvođenih bivšim učenikom Hrvojem Horvatićem, pokrenut je rad GIMNET-a, sličnog kluba koji je, osim kao okupljalište mladih, zamišljen kao prostor za predstavljanje umjetničkog stvaralaštva, ne samo gimnazijalaca, nego uopće. Tijekom nekoliko godina on je razvio bogatu kulturno-umjetničku djelatnost, organizirajući koncerte, izložbe, turnire, performance, slušaonice i video-slušaonice $u$ bivšem klupskom prostoru i gimnazijskom dvorištu. Zahvaljujući tome su se varaždinskoj mladeži, osim domaćih, predstavljali umjetnici, posebno glazbenici iz susjednih i zapadnoeuropskih zemalja, ali i gosti iz Kanade i SAD-a. ${ }^{184}$ Ova je djelatnost nakon nekoliko uspješnih godina, također zamrla. Danas je podrumski prostor bivšeg Kluba nažalost neiskorišten i prazan. Povremeno se i danas javljaju ideje o revitalizaciji učeničkog kluba, a to je na neki način i povod za pribavljanje sredstava za obnovu i opremanje njegovog neiskorištenog prostora.

\footnotetext{
181 Isto, Varaždinske vijesti, br. 43 od 31. X. 1991., str. 11.

182 Vlasnici su bili Josip i Krešlmir Čop (op. a.).

183 "Klub Gimnazije ponovo otvoren, Umjesto 'Peti tri' - 'Palestra' ", Varaždinske vijesti, br. 49 od 12. XII. 1991., str. 11.

184 Prva gimnazija Varaždin, Ljetopis za šk. g. 2006/7., str. 11.
} 


\section{ZAKLJUČAK}

Omladinski klub V3, utemeljen sredinom 60-ih godina XX. stoljeća, primarno je bio osnovan s namjerom da se osigura odgovarajući prostor namijenjen boravku učenika-putnika. No ubrzo je prerastao u prostor u kojem su kreirani, uvježbavani i izvođeni programi zabavnog i kulturno-umjetničkog karaktera poput plesnih večeri, dramskih, literarnih i glazbenih manifestacija. Najveći dio priređenih programa u početnom razdoblju njegovog djelovanja proizveli su učenici Gimnazije. Ograničen statičkim i sigurnosnim uvjetima na II. katu gimnazijske zgrade i prirodnom smjenom generacija, ovaj plodan rad je nakon nekoliko uspješnih godina počeo posustajati. Osiguravanjem novog prostora u preuređenom podrumu južnog krila školske zgrade, tijekom 70 -ih i početkom 80 -ih godina XX. stoljeća Klubu je omogućen novi uzlet. Novi prostor Kluba prvenstveno je poslužio potrebama njegove razgranane aktivnosti, održavanja raznovrsnih javnih događanja, kulturno-zabavnih priredaba te za rad slobodnih aktivnosti čime je gimnazijalcima omogućeno korisno provođenje slobodnog vremena. Za razliku od prethodnog razdoblja, u njegovoj su organizaciji pred polaznicima Gimnazije, a često i pred širim auditorijem, uz učenike nastupali istaknuti umjetnici, književnici, glazbenici i glazbeni sastavi, sportaši, društveno-politički djelatnici i znanstvenici s područja čitave tadašnje države. Kako je nakon rekonstrukcije gimnazijske zgrade to bio jedini veći uređeni prostor u školi, za svoje potrebe ga je obilato koristila sama Gimnazija. U njemu su priređivane školske priredbe, kulturne i političke manifestacije, skupovi i sastanci, a povremeno su ga kao prostor za odvijanje vlastitih aktivnosti, koristile i neke vanjske udruge i organizacije.

Premda je poticaj za njegovo osnivanje dala gimnazijska Omladinska organizacija, Klub je ubrzo prerastao u samoupravnu, financijski gotovo neovisnu udrugu koja je kao posebno registrirana udruga građana funkcionirala pod okriljem Gimnazije. Njome je upravljalo izabrano kolektivno tijelo Uprave kluba. Činilo ju je između 20-ak i 50-ak članova, popunjavanih svake godine priključivanjem novih članova iz prvih razreda, najčešće prema preporuci starijih. Ako su bili spremni uložiti dio svojeg slobodnog vremena i potrebnih vještina, članovi su se, prema potrebama i vlastitim sklonostima, opredjeljivali za davanje podrške određenim djelatnostima. Dogovarali su i određivali dežurstva, rukovali tehnikom, čistili i održavali prostore i samostalno vodili računa o prikupljenom novcu. Klub je posjedovao vlastiti bankovni račun, a rad i upravljanje Klubom bili su propisani Pravilima, a kasnije i Statutom prilagođavanim aktualnoj zakonskoj regulativi. Tako su članovi razvijali odgovornost, demokratičnost i stjecali upravljačke kompetencije i socijalne vještine. 
Značajan doprinos dužem razdoblju kontinuiranog uspješnog djelovanja Kluba svakako je osiguran višegodišnjim bespoštednim angažmanom istog voditelja koji je u osobi prof. Franje Bračka pružao stručnu pomoć i predstavljao neposrednu vezu kluba i škole. Česte izmjene na toj dužnosti u kasnijem razdoblju, uz redovitu generacijsku smjenu u članstvu Uprave Kluba, dovodile su do oscilacija u radu. Povećana inflacija i pojava konkurenata u priređivanju disco-večeri narušavali su i financijsku samostalnost Kluba. Rješenje se tražilo u čvršćoj vezi Kluba i školske Omladinske organizacije čime je dijelom ograničavana njegova autonomija. No svako je novo vodstvo svoje planove uglavnom oslanjalo na već prokušane aktivnosti kojima se nastojalo privući mladež ili osigurati financiranje djelatnosti. Društveno-političke promjene i ratne prilike početkom 90 -ih godina potpuno su zaustavile djelovanje Kluba, a njegov je prostor u novim okolnostima škola nastojala praktično iskoristiti.

\section{IZVORI I LITERATURA}

1) Gimnazija - SC "Gabriel Santo" Varaždin, Varaždin 1986.

2) Gimnazija u Varaždinu 1636.- 2006., Varaždin 2006.

3/ Gimnazijskih 380 godina, katalog izložbe u povijesnom odjelu GMV 12. X._19. XII. 2016.

4/ Prva gimnazija Varaždin, Ljetopisi škole 2005.- 2010.

5/ Pisma gospode: Andreja Dermola, Krešimira Ferinca, Jože Haluze, Željka Pilipovića, Mirne Rukavina-Bakšaj, Franje Bračka, Tomislava Ribića, Vladke Brgles, Dubravka Lončara, Dinke Bertapele, Darija Milkovića, Dubravke Furijan, Josipa Novaka, Tihomira Englera, Milade Erhatić, Miljenke Štimec, Igora Čolakovića, Ivice Kruhoberca, Mirana Bojanića-Morandinija (u posjedu autora).

6/ Varaždinske vijesti. 


\section{PRVA GIMNAZIJA VARAŽDIN, YOUTH CLUB V3}

As a part of Gimnazija Varaždin, Youth Club V3 was named after and founded on the 21st of September 1965 at the anniversary of the plight of V3 (fifth three) class of Kragujevac students. At first its activities were confined to the former Gimnazija drawing room which was at the time the biggest room in the school. After the reconstruction process of the Gimnazija building in the period between 1971 and 1973, aided by student volunteers, the basement of the school was refurbished for the purposes of the club activities. It continued to flourish until the start of the war which in 1990s marked the collapse of Yugoslavia and contributed to the establishment of the indepedent Republic of Croatia.

As a student club which had only limited autonomy within the school, the club developed a rich and varied plan of activities which entailed the organization of public events, cultural and entertainment events intended for Gimnazija students and general public as well. Thanks to its own earnings, the club was partially independent in terms of its finances and its activities were mostly organized independently by the students with an indirect supervision of the school management. The club organized various spectacles for its students which were delivered by distinguished artists, writers, musicians and music groups, scientists, athletes, political activists and other important figures from the entire territory of Yugoslavia. Gimnazija students were thus offered not only a high-quality activity plan for their free time, but also a form of entertainment because the club would regularly, once a week set up disco-evenings as it was the only discoclub in Varaždin for many years.

After the beginning of the War of Independence and the newly emerged social, political and economic system in the early 1990s, the activity of the youth club V3 was spontaneously discontinued. Its emptied premises were afterwards used by the Gimnazija management for a fast food facility catering to its students.

Key Words: Prva gimnazija Varaždin; youth club; youth culture and entertainment; Varaždin. 